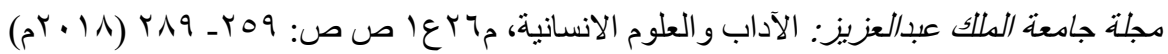

$$
\begin{aligned}
& \text { DOI:10.4197 / Art.26-1.11 }
\end{aligned}
$$

نموذج العلاقات بين المكونات المعرفية للاستدلال ومستو اها لدى تلاميذ الصف الصف

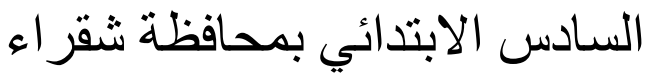

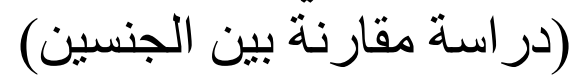

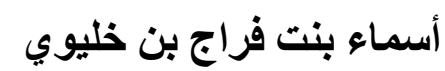
استاذ علم النفس المساعد جامعة شقر اء، المدلكة العربية السعودية

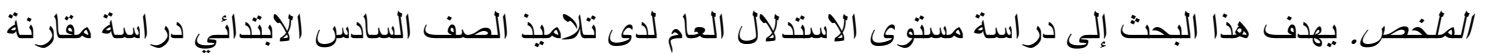

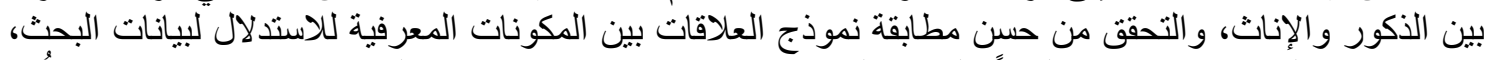

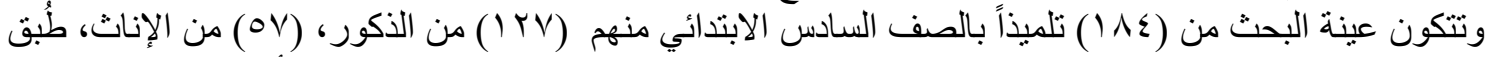

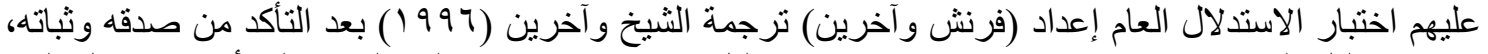

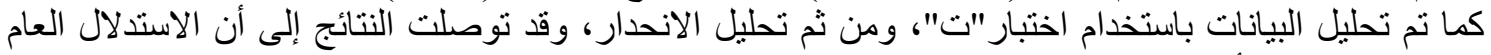

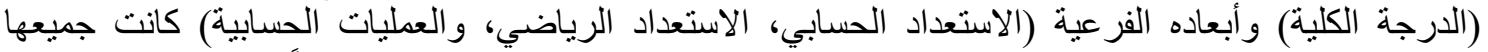

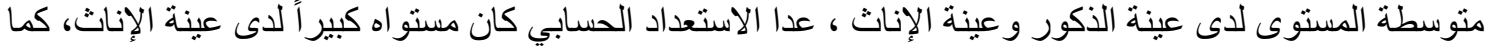

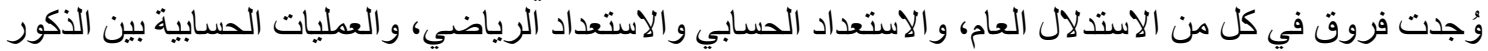

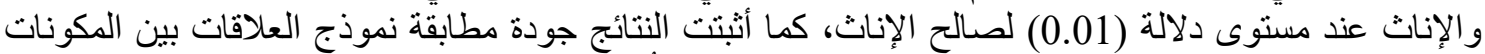

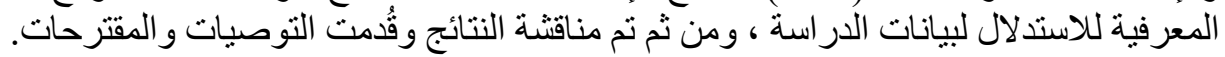
كلمات مقتاحية : الاستدلال العام ، الاستعداد الحسابي ، الاستعداد الرياضي ، العمليات الحسابية ، تلاميذ الصف السادس الابتدائي. 
هذا البحث إلى دراسة إحدى هذة العمليات الأساسية في التحصيل الرياضي وهو الاستدلال العام

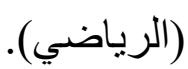

ويتمثل الاستدلال في قدرة الفرد على معرفة العلاقات بين وقائع معينة تعطى له بحيث يمكن على اله ضوء هذه المعرفة أن يحكم ما إذا كانت نتيجة

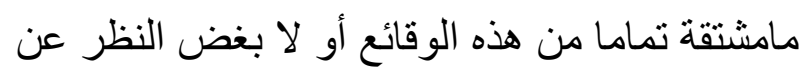

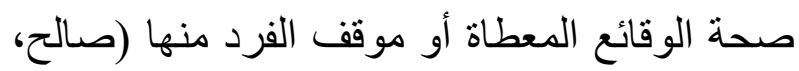

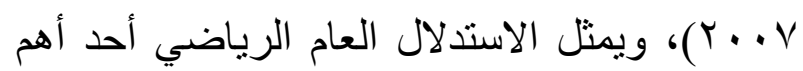

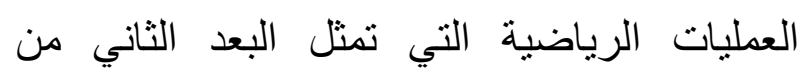
مكونات القدرة الرياضية، ومعها المعرفة الرياضية التي تتضمن المعرفة المفاهيمية والمعرفة الإجر ائية، وحل المشكلات وماور اء المعرفة، و المحتوى الذي يوضح المجالات و المعايير الأساسية للرياضيات

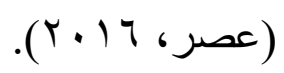

ويشير كارسون Carson, (1984) إلى أن كريفين قدم الاستدلال على أنه محاولة و اعية لتجنب الوقوع في مغالطات التحليل المنطقي، ويعتمد الاستدلال على تقديم عنصر جديد يختلف عن المعطيات التي انطلق منها الاستدلال ،وذلك من خلال استنتاج يعتمد

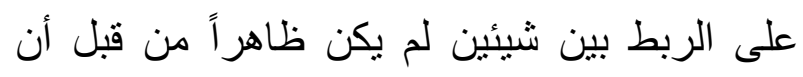
بينهما علاقة ما، مع مر اعاة صحة المنطق.

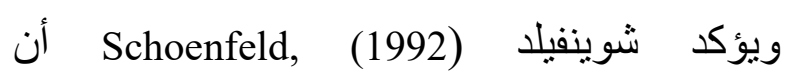
الرياضيات أكثر من مجرد حسابات، وإنما تكثف عن الأنماط الخفية التي تساعدنا على فهم العالم من حولنا بداية من التعامل مع البيانات و القياسات والملاحظات وحتى الاستدلال، ويذكر سينجلي لئي وبنجي Singley \& Bunge, (2014) أن فهم علامة وكني التساوي (=) ليس إلا إثبات لمركزية الاستدلال في

\section{مقدمة}

طبقاً لنظرية جان بياجيه في النمو المعرفي ينتمي تلاميذ الصف السادس الابتدائي إلى مرحلة العمليات Concrete Operational المادية (الإجرائية العيانية)

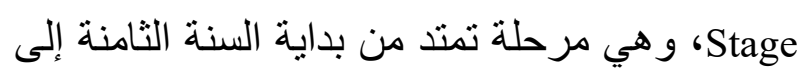
نهاية السنة الحادية عشرة من العدر، وفيها يستطيع الطفل إجراء عمليات الاستدلال ولكن على المستوى عنى عن

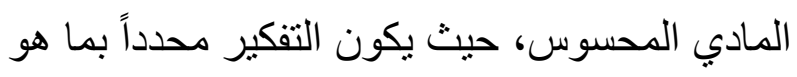
عيني أو محسوس فيما يقع في خبرة الطفل المباشرة، مما يُصعب على تلاميذ هذة المرحلة إجراء الاستدلالات المجردة، والتي تمثل العملية الجوهرية في إجراء العمليات الحسابية، وحل الاهل المسائل الرياضية. فالرياضيات علم تجريدي يستخدم الاستدلال في لئي الوصول إلى العلاقات العددية و الهندسية وغير هما،

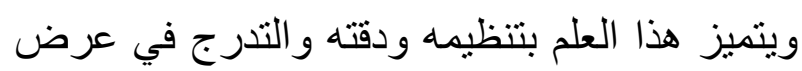
معلو ماته؛ مما يسهم في الوصول إلى تفسير ات دقيقة

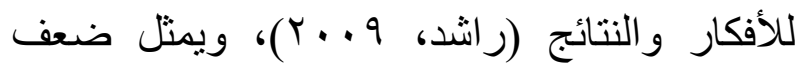

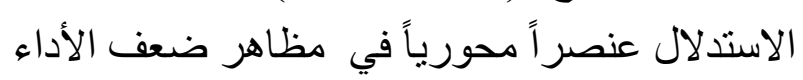

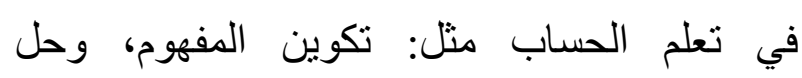
المشكلة، والصعوبات المرتبطة بالعمليات المعرفية

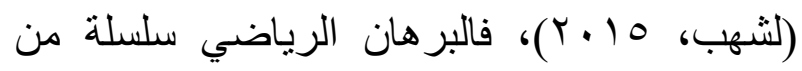

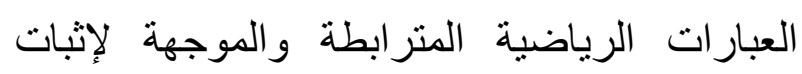
صحة نتيجة معينة عن طريق الاستدلال والمنطق و غير هما (أبوزينة، 7 و 9 ()).

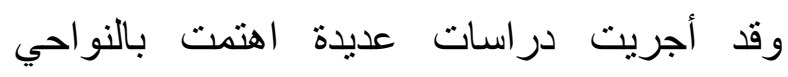

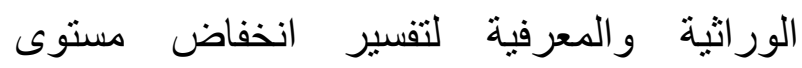
التحصيل الدراسي، وزيادة نسب صعوبات تعلم

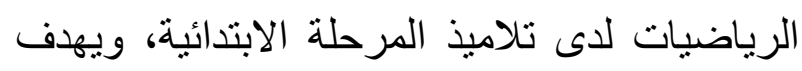


المعرفة، في ضوء ذلك نجد أن مهارات ما وراء الاستدلال من أهم مهار ات العلوم الطبيعية.

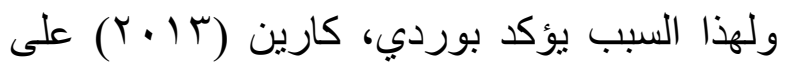
أهمية مشاركة المتعلم وتفاعله في عملية الاستدلال

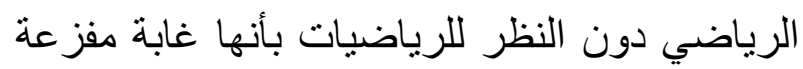

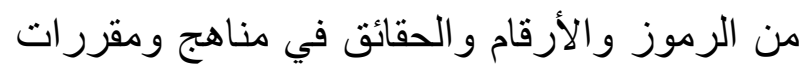
للحفظ و الاستظهار وليس للفهم، وبهذا الثنكل يمكن فئن

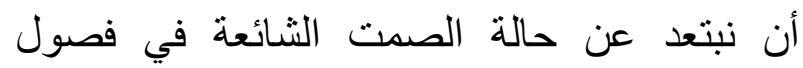

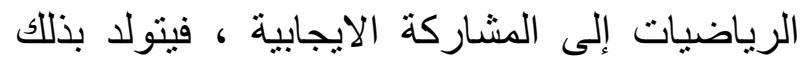

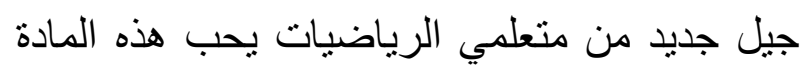

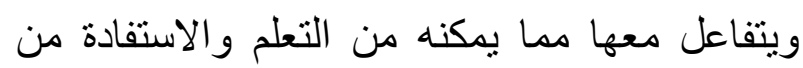

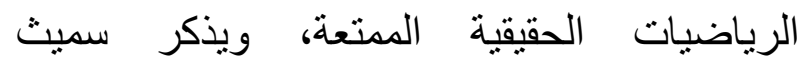
وتومسون Smith \&Thompson, أن (2007) كثير اً من الطلاب يدركون الجبر كممارسة رمزية لا معنى لها، ولكن من خلال التركيز على الاستدلال

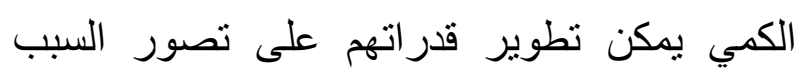

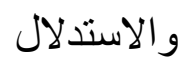

وقد استدعى ذلك إعداد دراسات عديدة لتنمية الاستدلال لدى الطلاب ومنها دراسة نايك وآخرين

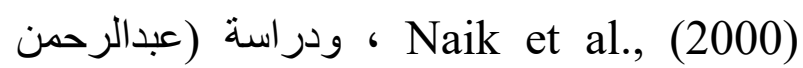
(Y...

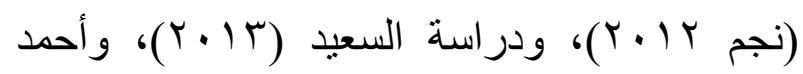

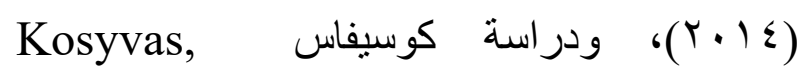

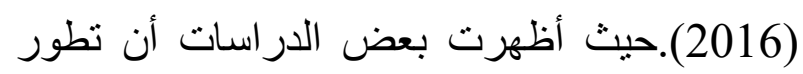

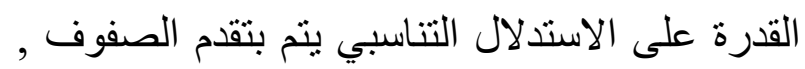

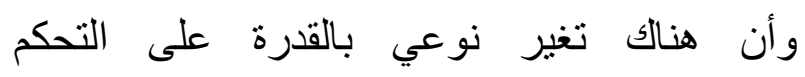

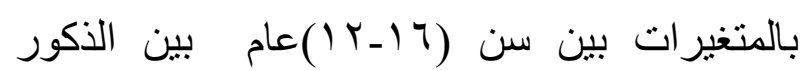
و الإناث . بالغير ات
الرياضيات، كما أن هنالك أدلة قوية على وجود علاقة بين الاستدلال و الأداء الحسابي. ويذكر كانث (2011) Kنnuth, من خلال در استه

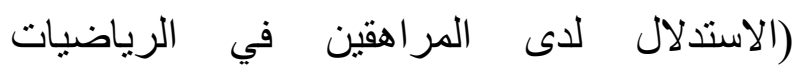
والجالات غير الحسابية) أن هناك قلقاً دائماً تجاه

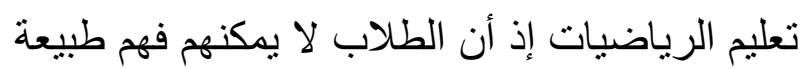

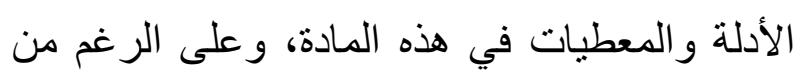
أهمية الاستدلال في التعلم واهميته الحسابية ، فإن النان

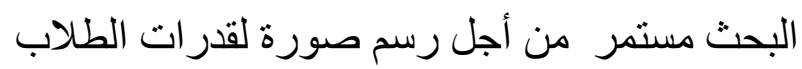

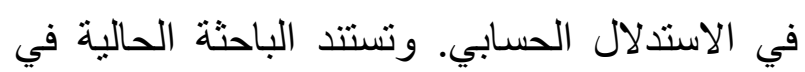
ذللك إلى الدراسات السابقة التي أكدت العلاقات بين الإلئ

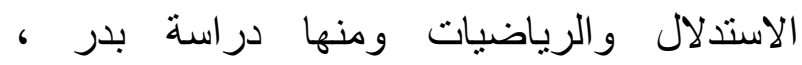

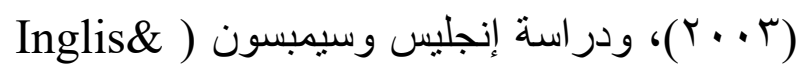

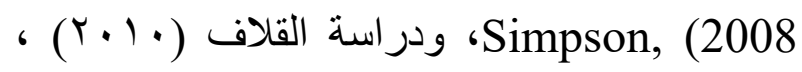

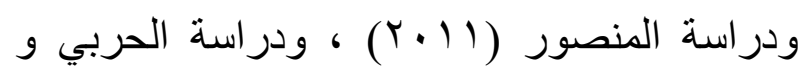

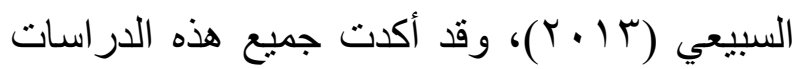
العلاقة بين تحصيل الرياضيات و الاستدلال. ولا تقتصر أهية الاستدلال الرياضي في علاقته

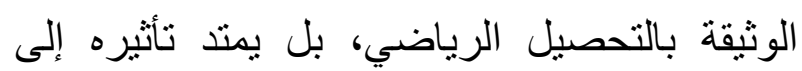

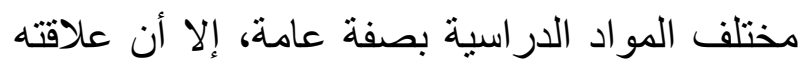

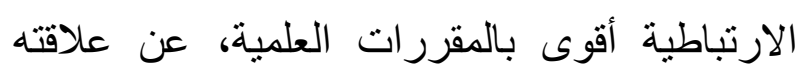
بالمقررات اللغوية أو الإنسانية، وقد كثف الإنف تحليل علئل

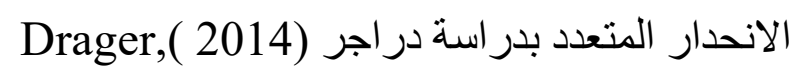
أن القدرة على الاستدلال المجرد تفسر نسبة كبيرة

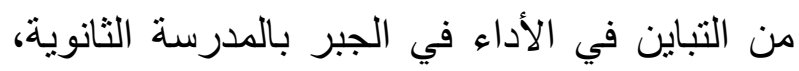

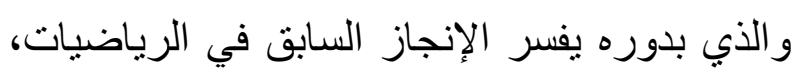

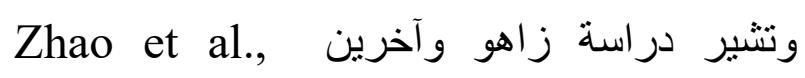

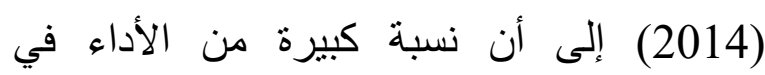
الرياضيات يمكن توقعه مباثرة من خلال ما وراء 
التي يعتمد عليها التحصيل الدراسي في العلوم الطبيعية والإنسانية أيضاً، لذا وجب الاهنمام بدر اسة

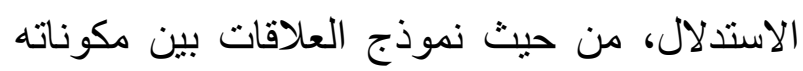

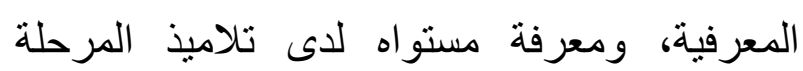
الابتدائية، واستقصاء الفروق فيه وبنه فين الذكور والإناث، حيث أكدت أغلب الدراسات على تفوق الأكور على الإناث، بينما تؤكد دراسات أخرى على الإنى

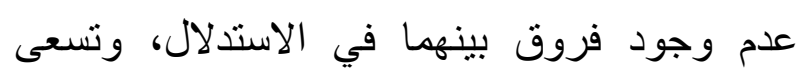

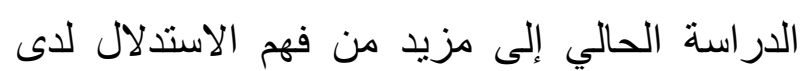
تلاميذ الصف السادس الابتدائي. أسئلة الار اسلة المدة

يمكن التعبير عن مشكلة البحث بالأسئلة التالية:

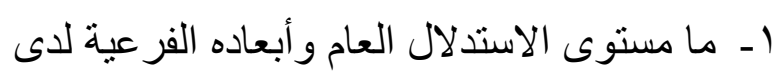

تلاميذ الصف السادس الابتدائي (العينة الكلية)؟

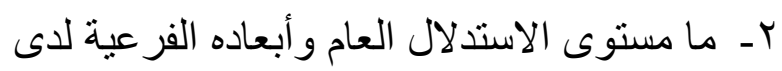

تلميذات الصف السادس الابتدائي (الإناث)؟

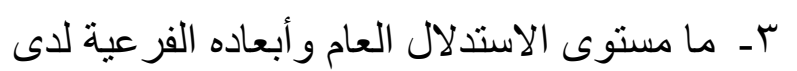

$$
\text { تلاميذ الصف السادس الابتدائي (الذكور)؟ }
$$
ع - هل توجد فروق في مستويات الاستدلال العام وأبعاده الفرعية بين الذكور والاناث من تناميذ

$$
\text { الصف السادس الابتدائي؟ }
$$

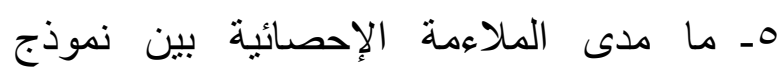
العلاقات بين متغيرات الدراسة وبيانات تلاميذ الصف السادس الابتدائي، كما تعكسها مؤشرات الملاعمة الإحصائية. أهداف الدراسة الإعة المانة تهذف هذا الدر اسة إلى ما يلي: أو لا: التعرف على مستوى الاستدلال العام وأبعاده الفرعية وهي: الاستعداد الحسابي، الاستعداد
مما سبق تتضح أهمية الاستدلال كقرة عقلية لها

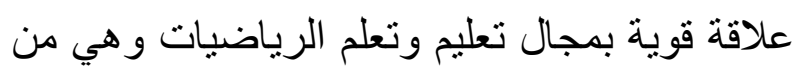
العلوم الأساسية التي يعتمد عليها التحصيل الدراسي وني لفي

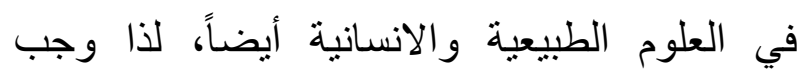
الاهتمام بدر اسة الاستدلال لتفسير مشكلات الطلاب الانه التعليمية. مشكلة الدراسة تؤكد نتائج أغلب الدراسات السابقة التي اهتمت بدراسة الفروق بين الجنسين في القدرة على لأل الاستدلال على تفوق الذكور على الإناث في القدرة

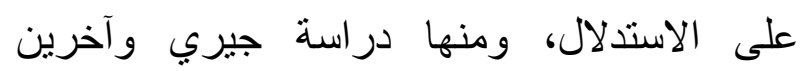

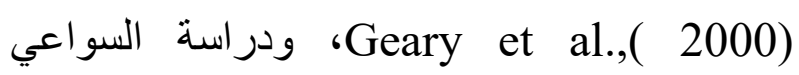

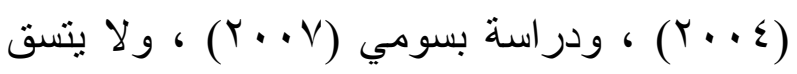
ذلك مع ما لاحظته الباحثة من خلال الخبرة الميدانية ودرية

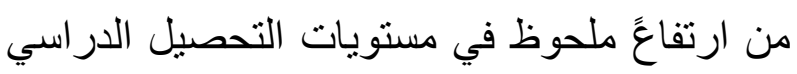
في الحساب لدى تلميذات الصف السادس الابتدائي

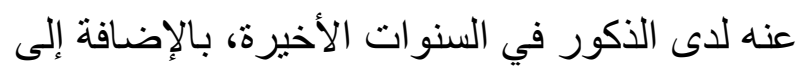
المشاركات النشطة من الإناث مقارنة بالذكور في لإني المسابقات و المحافل الداخلية والخليجية و الدولية

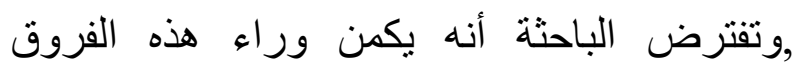
اختلاف في القدرة الاستدلالية لديهما، وتستتد الباحثة في ذللك إلى نتائج در اسة عطا الله (ع . . ب)، ودر اسـة

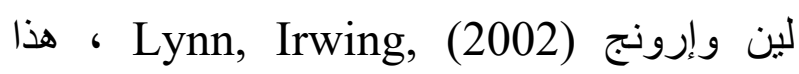
الاختلاف في نتائج الدراسات السابقة مبررا يدفع إلى إجراء المزيد من الدراسات لمعرفة الفروق بين الجنسين في المملكة العربية السعودية. فالاستدلال كقدرة عقلية لها علاقة قوية بتعلم مجالات أكاديمية عديدة ومن أهمها على الإطلاق تعلم مجال الرياضيات، وهو من العلوم الأساسية 
لبناء برامج تتمية هذه القدرات لدى هذه الفئة من الطلاب.

- تطوير مناهج الرياضيات في ضوء المقارنة المقار بين

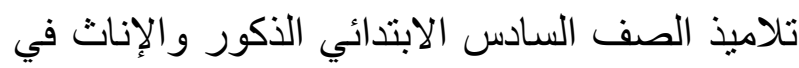
مستوى الاستدلال العام ومستوى كل من الاستعداد

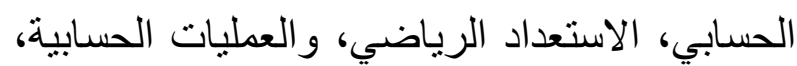
بما يتو افق مع خصائص كل مجمو عة.

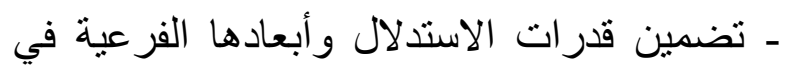
مناهج الرياضيات، للاستفادة منها في تنمية التحصيل الأكاديمي للرياضيات، وتنمية وتطوير التفكير الاستدلالي لدى تناميذ الصف السادس الابتدائي.

\section{حدود الار اسة}

تتمثل حدود الدر اسة فيما يلي: ـ الحدود الزمنية: طُبقت الدر اسة الميدانية للبحث

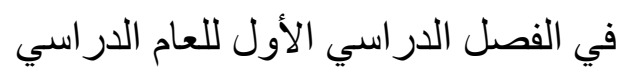
ه $1 \leqslant r \Lambda / 1 \leqslant r V$

ـ الحدود المكانية: اقتصر هذا البحث على تلاميذ وتلميذات من مدارس المرحلة الابتدائية بإدارة تعليم

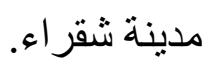

الحدود الموضوعية: تتمثل الحدود الموضو عية لهذا البحث في التحقق من جودة مطابقة نموذج العلاقات

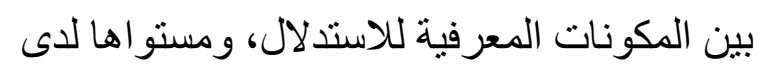
تلاميذ الصف السادس الابتدائي في ضوء متغير الجنس بمدينة شقر اء، من خلال الدر اسة المقارنة.

\section{مصطلحات الدراسة:}

الاستدلال: تعرف الباحثة الاستدلال على أنه: "قدرة عقلية تبدو في أداء عقلي معرفي مجرد بستخدم
الرياضي، والعمليات الحسابية لدى تلاميذ الصف السادس الابتدائي الذكور والإناث.

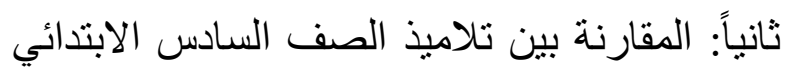
الذكور و الإناث في مستوى الاستدلال العام ومستوى كل من الاستعداد الحسابي، الاستعداد الرياضي، و العمليات الحسابية. ثالثاً: التأكد من الملاءمة الإحصائية بين نموذج العلاقات بين متغيرات الدراسة وبيانات تلاميذ الصف السادس الابتدائي، كما تعكسها مؤشرات الملاعمة الإحصائية.

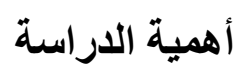
للار اسة أهمية نظرية وأخرى تطبيقية نوجزايه هما فيما يلي: أولاً: الأهمية النظرية: - معرفة مستوى الاستدلال العام كقدرة معرفية عليا وكذللك أبعاده الفر عية وهي: الاستعداد الحسابي، الاستعداد الرياضي، والعمليات الحسابية لدى تلاميذ الصف السادس الابتدائي. - يُعد البحث اسهاماً نحو مزيد من فهم الفروق بين الجنسين في النواحي المعرفية، من خلال المقارنة بين الذكور والإناث في مستوى الاستدلال العام ومستوى كل من الاستعداد الحسابي، الاستعداد الرياضي، و العمليات الحسابية.

\section{ثانياً: الأهمية التطبيقية:}

- يُعد تحديد مستوى الاستدلال العام و أبعاده الفرعية الاستعداد الحسابي، الاستعداد الرياضي، والعمليات الحسابية لدى تناميذ الصف السادس الابتدائي الذكور والإناث خطوة تشخيصية كمية، ومنطلقاً 


\section{1 ـ مفهوم الاستدلال:} ـ الاستدلال لغة: في معجم المعاني الجامع إسنتِدلال:

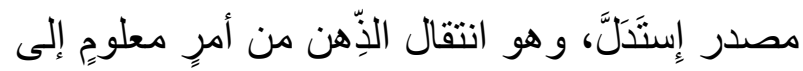

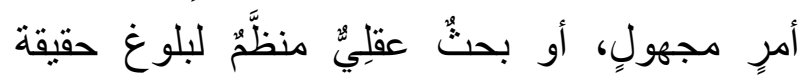
مجهولة انطلاقًًا من حقيقة معلومةٍ استدلالاً منطقياً، أو استنتاج قضيّة من قضيّة أخرى، أو استنتاج قضيّة من قضايا أخر ، وفي الفقه : ذِكْر دليل ليس

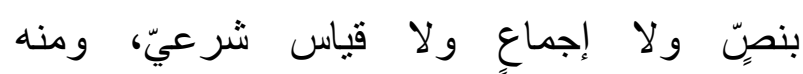
استدلال مباشر: ما كانت عمليَّة الاستدلال فيه

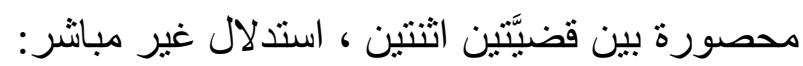
الذي تستنبط فيه النتيجة من قضيَّتنين أو أكثر. ـ الاستدلال اصطلاحاً: تباينت تعريفات الاستدلال والقدرة الاستدلالية و التفكير الاستدلالي ونذكر منها بعض التعريفات فيما بلي: - تعريف باير (1987) Beyer, مهارة تفكيرية تقوم بدور المسهل لتنفيذ أو ممارسة عمليات معالجة المعلومات التي تضم التفسير والتحليل و التركيب

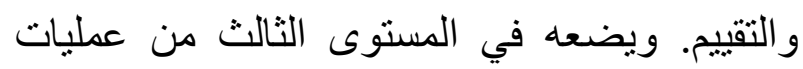
التفكير المعرفية بعد إستر اتيجيات التفكير المعقدة، ولهية (حل المشكلات، و اتخاذ القرار، وتكوين المفاهيم). - تعريف أبو حطب \& صادق (199 1): ذللك النمط من التفكير الذي يتطلب إستخدام أكبر مقدار من المعلومات بهدف الوصول إلى حلول تقاربية سو اء كانت الحلول انتاجيه أو انتقائيه.

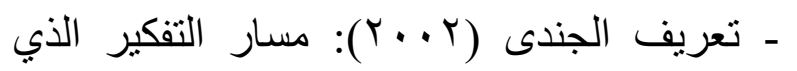
يظهر فيه الأداء العقلى حيث يتقدم العقل بواسطته

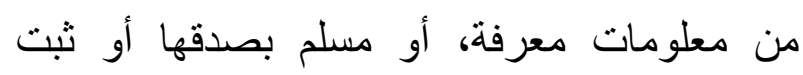
صدقها إلى معرفة المجهول الذى يتمثل فى نتائج
المقدمات الصادقة في الوصول إلى نتائج تقاربية من خلال ر ابطة منطقية". نموذج العلاقات: تمثيل للعلاقات النظرية بينه بعض المتغيرات، بعد التحقق من الملاعمة

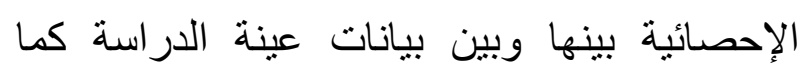
تعكسها مؤشر ات الملاعمة الإحصائية.

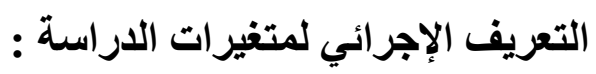

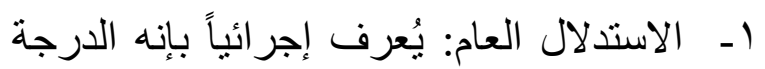
التي يحصل عليها التلميذ في اختبار الاستدلال العام (الدرجة الكلية) إعداد أكستروم، فرنش، وهارمان، ودير مين ترجمة الثيخ و آخرين (1997 ( ).

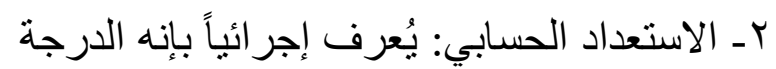
التي يحصل عليها التلمبذ في اختبار الاستعداد

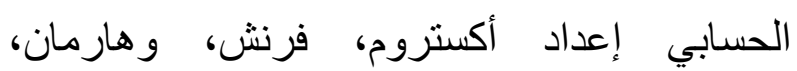
وديرمين ترجمة الثيخ وآخرين (1997 ( ).

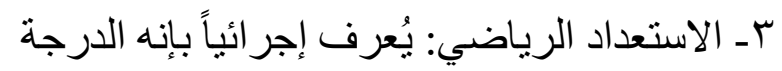
التي يحصل عليها التلميذ في اختبار الاستعداد

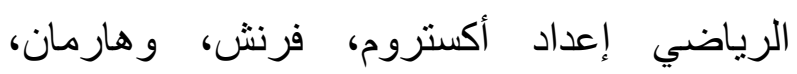
ودير مين ترجمة الثيخ و آخرين (99 99 ( ). ع ـ العمليات الحسابية: تُعرف إجر ائياً بإنها الدرجة التي يحصل عليها التلميذ في اختبار العمليات الحسابية إعداد أكستروم، فرنش، وهارمان، ودير مين ترجمة الثيخ و آخرين (99 99 ( ).

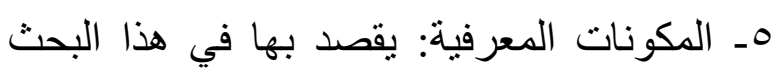
مكونات الاستدلال العام وهي الاستعداد الحسابي الاستعداد الرياضي، و العمليات الحسابية.

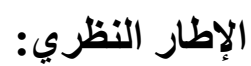
فيما يلي تتناول الباحثة مفهوم الاستدلال، ومهار ات ات الإل التفكير الاستدلالي، وأهمية الاستدلال الرياضي. 
ـ تحديد مدى كفاية الأدلة والثواهد التى قدمها المدعى لما يدعيها من حجج، ومدى مناسبة هذه الأدلة للادعاء.

- تقييم الحجج، ويعني: الحكم على ما إذا كانت الحجة مقبولة أو غير مقبولة.

- إنتاج الحجج، ويتضمن ضرورة فئه إنتاج سلسلة متر ابطة من الاستدلالات السليمة لتأييد ما ندعيه. (مركز تتمية الإمكانات البشرية، و99 ( 9 ). ويبين ماسبق أن التفكير الإستدلالي له دورة الفعال في متابعة منطقية الحجج الإستقر ائية والإستنباطية التي تصدر في الموقف (محاجة)، لذا بمكن للتفكير الإستدلالي أن يتطور نتيجة إلى أشكال من المحاجة

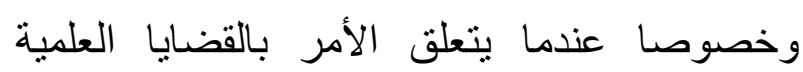
والحسابية، حيث يسعى الفرد إلى متابعة منطقية الحجج المضادة وأنتاج افكار جديدة. أهمية الاستدلال الرياضي:

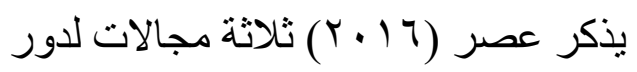
الاستدلال الرياضي في تحصيل الرياضيات وهي: ( ) الاستدلال الرياضي في المعرفة المفاهيمية: ويقصد به تحديد القواعد والتعميمات المرتبطة بالمفاهيم الرياضية، وتفسير الرموز و العلاقات والجدليات المرتبطة بها، بالإضافة إلى استنتاج

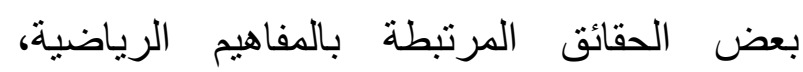
واستخدام النماذج والأنماط الرياضية والأمثلة بلة الرئة والحالات الخاصة لاستقراء القوانين و الخصائص و التعميمات و النتائج و الفرضيات المرتبطة بالمفهوم

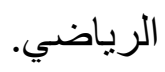
r) الاستدلال الرياضي في المعرفة الإجرائية: ويقصد به إجراء الخوارزميات والإجراءات
ضرورية لهذه القضايا، أو تللك المعلومات دون اللجوء للتجريب. - Barbey\& Barsalou, تعريف باربي وبارسالو (2009) هو السمة المميزة للفكر الإنساني، ودعم

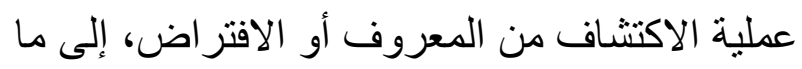
هو غير معروف أو ضمني في تفكير الفرد.

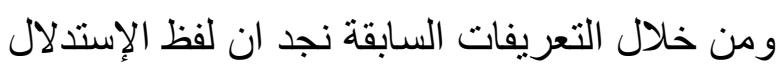
فى علم النفس المعرفى يستخدم للالاله على معاني مختلفة من بينها الدليل أو الحجة أوتقييم المعتقدات وصحة الادعاءات، كذللك ظهر بمعنى القدرة على بلى

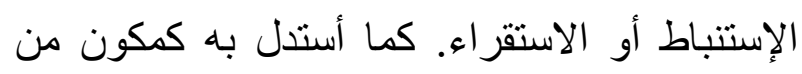
مكونات التفكير أو القدرة على حل المشكلات.

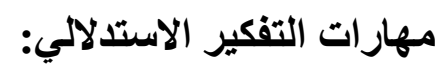
للاستدلال ثناث مهار ات أساسية هي: الاستقراء Induction Conculsion معرفي يتميز باستتناج القاعدة الكلية من الحالات

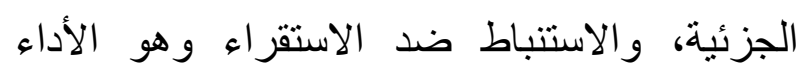
العقلي المعرفي الذي يتضمن تطبيق القواعد الكلية على الحالات الجزئية، أو استنباط الحالات الجزئية من القاعدة الكلية، أما الاستتناج فهو التوصل إلى التى نتيجة من مقدمات وبيانات متوفرة بدليل رياضي مسلم بصحته، وللتفكير الاستدلالي مهار ات عديدة

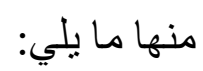
ـ التعرف على الحجج: أي القدرة على التمبيز بين الإدعاء المدعم بأسباب منطقية و المرسل. ـ تحليل الحجج: ويتضمن تحديد الادعاء، تحديد الأسباب المعطاه لتأييد الادعاء، المقدمات أوليعن الافتر اضات المنطقيه المذكورة و غير المذكورة. 


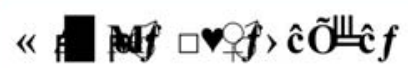

\begin{tabular}{|c|c|}
\hline الاستدلال الكمي & الرياضيات \\
\hline قوة السياقات الواقعية & قوة التجريد \\
\hline التطبيقات النوعية & قوة التعيم \\
\hline اعتمادية كبيرة على & بعض الاستقلالية عن \\
\hline اعتمادية علي المجتمع & الاستقلالالة عيّاق المحتمع \\
\hline 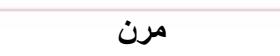 & غير مرنة \\
\hline طرق خاصة & طرق ولوغاريتمات \\
\hline مشكلات ضعيفة البنية & مشكلات جيدة البنية \\
\hline التقير أمر بالغ الأهمية & التقريب \\
\hline مجال بيني & متخصص بشدة \\
\hline وصف المشكلة & حل المشكلة \\
\hline فرص عديدة للممارسة & للممارسية خارج الصفي \\
\hline
\end{tabular}

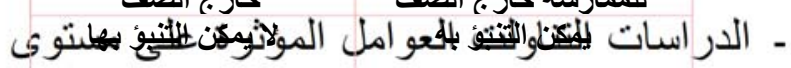

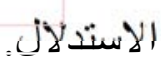

ـ ـ الدر اسات التناولت بر امج تنمية الاستدلال.

- دراسات تناولت الفروق بين الجنسين في

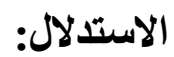

دراسة جيري وآخرين (Geary et al., 2000): تهدف هذه الدر اسة إلى المقارنة بين الذكور والإناث

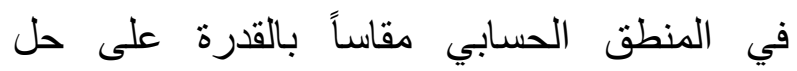

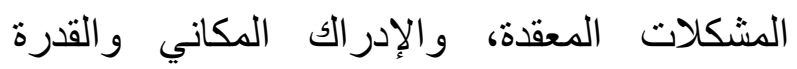

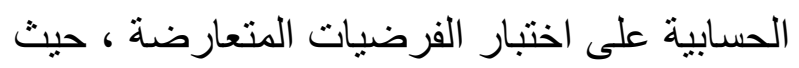

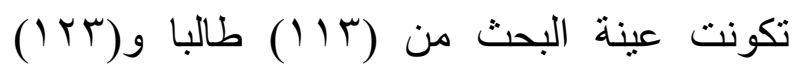
طالبة من طلاب الجامعة، طُبق عليهم اختبارات المنطق الحسابية، واختبار الذكاء، واختبار الإدراك

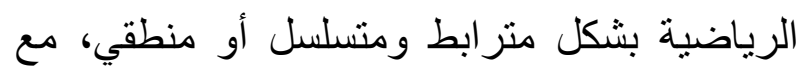

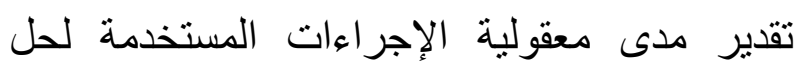

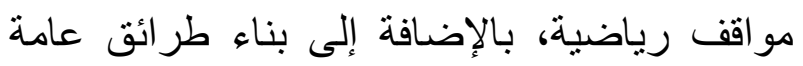

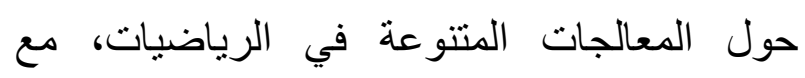
استتناج كيفية استخدام الطر ائق العامة على المواقف المشابهة ץ) الاستدلال الرياضي في حل المشكلات: ويقصد به بناء التوقعات وفرض الفروض وتحديد البيانات المرتبطة بها لفحص صحتها، مع تحديد طرائق الحل المناسبة, و إنتاج أفكار متتوعة ومختلفة حول المواقف المشكلة اعتماداً على الخبرة السابقة في الرياضيات, ورأخيراً إصدار أحكام حول النتائج واتخاذ قرار بقبولها أو إعادئ Madison, Bernard. معالجتها، ويقدم ماديسون، وبيرنارد

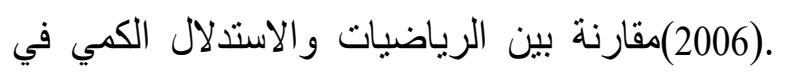

شكل (1). - (1). - (2006).

ويظهر الثكل (1) المقارنة بين الاستدلال الكمي والرياضيات وفق 11 بند من بنود الخصائص الرياضية لمعالجة العمليات الحسابية و الرياضبة في لريات التعلم. الار اسـات السابقة:

تنو عت أهداف ومجالات ومناهج و أدوات الدر اسات السابقة التي تناولت الاستدلال لدى عينات مختلفة، وفيما يلي نعرض بعضاً من هذه الدراسات وفقاً

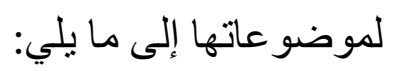
ـ الدراسات التناولت الفروق بين الجنسين في في التين

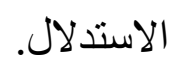
ـ الدراسات التناولت أثر محتوى المشكلة على مستوى الاستدلال. 
الدراسة من (•r T I ) طالباً بمنطقة العين التعليمية،

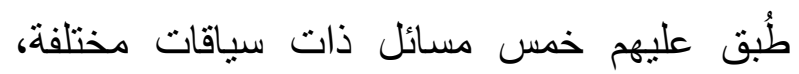

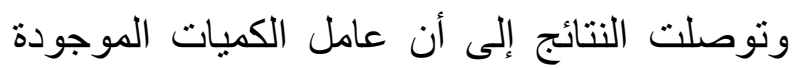
بالمسألة يؤثر في الاستدلال التناسبي، كما أظهرت

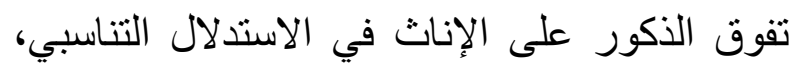

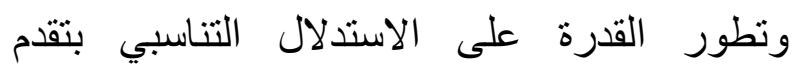
الصفوف.

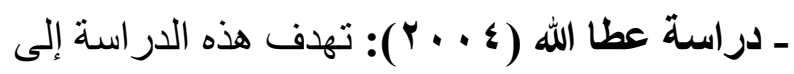
استقصاء تطور مستوى فهم عمليتي الملاحظة الانة والاستدلال لاى طلاب الصفين الثالث و السادس فلثن الأساسيين في مادة العلوم، حيث تكونت علان عينة البحث

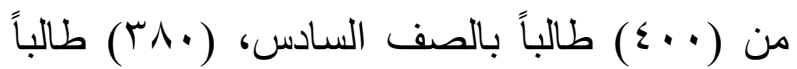

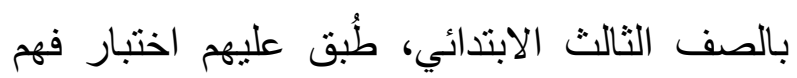

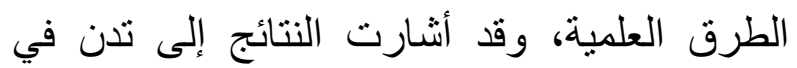

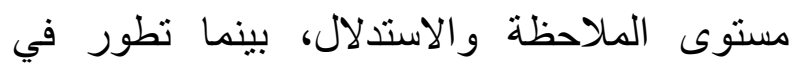
مستوى فهم عمليتي الملاحظة والاستدلال اهؤلاء الطلاب، ولم توجد فروق بين الذكور و الإناث فيهما.

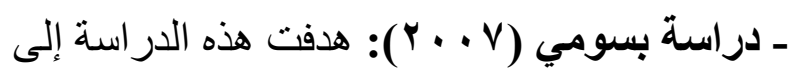

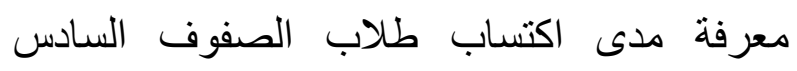

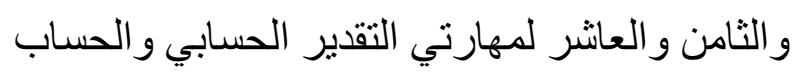

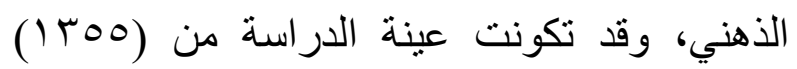

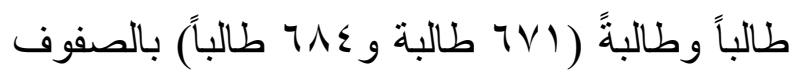

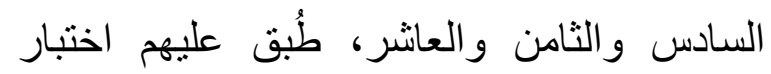
computational estimation test الحسابي(Reys \& Reys. 1991)، واختبار الحساب وريز للفير

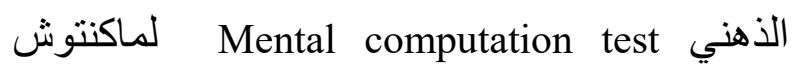
وآخرين ( McIntosh et al,1995)، وقد أظهرت النتائج أن منوسط أداء الطلاب بشكل عام في اختبار التقدير الحسابي متدن، وكان أداء الذكور في اختبار
الانكاني، وقد أظهرت النتائج تفوق الذكور على

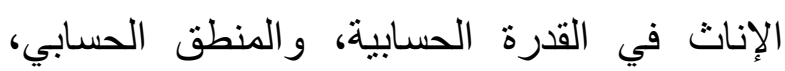

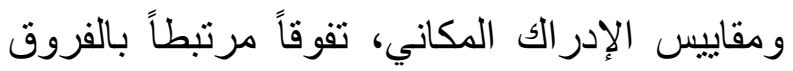
الفردية في الذكاء و القدرات المكانية، و والطلاقة

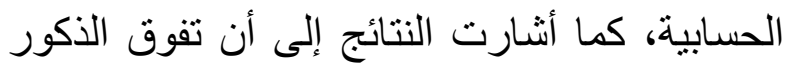

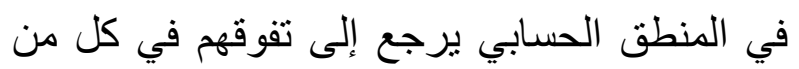
الطلاقة الحسابية و الإدر الك المكاني. دراسة لين وإرونج (Lynn, Irwing2002: تهدف الإدراف هذه الدراسة إلى تحديد مدى الفروق بين الجنسين

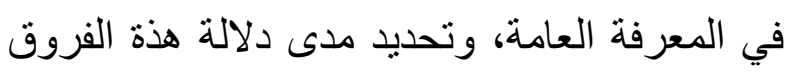

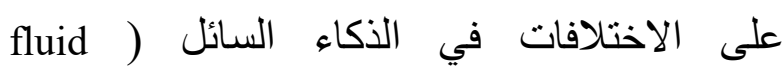
مقاساً بمقياس باديللي للاستدلال (intelligence

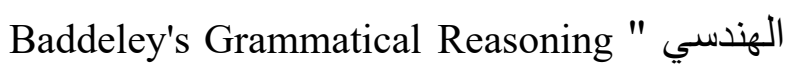
"Test

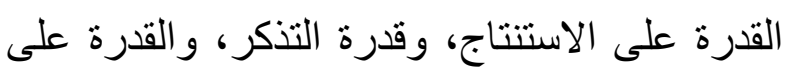

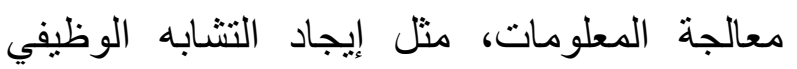

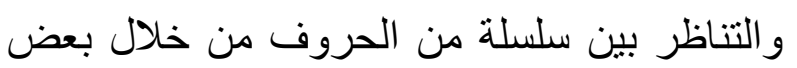

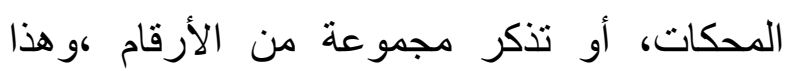

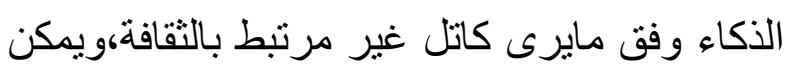

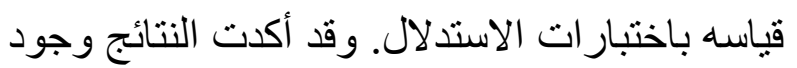

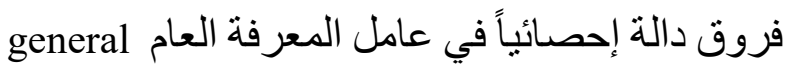
knowledge

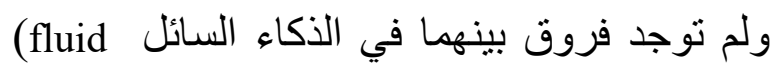
intelligence)

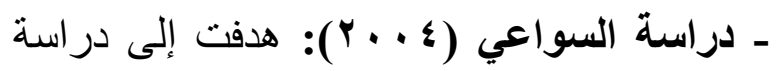
تأثثير العوامل المتعلقة بسياق المسألة في الاستدلال

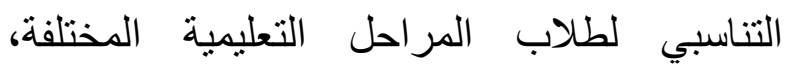

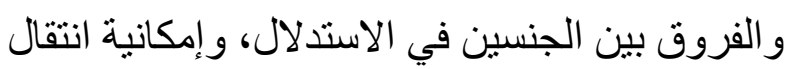
أثر التعلم من خبرة إلى أخرى، حيث تلكونت لالتين عينة 
et al., في المنطق الحسابي، وفسرت ذللك بتفوقهم في كل

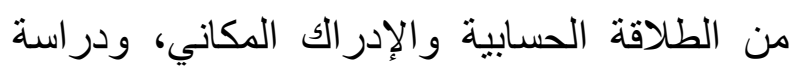

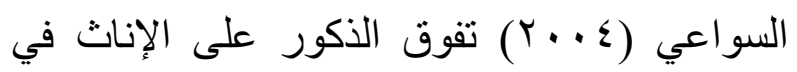

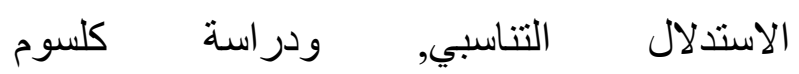

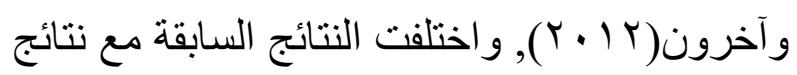

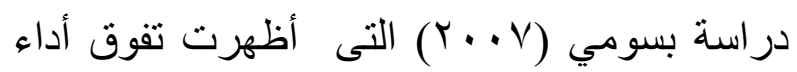

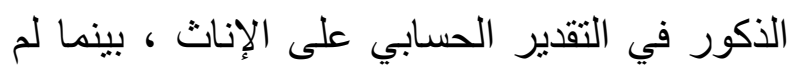

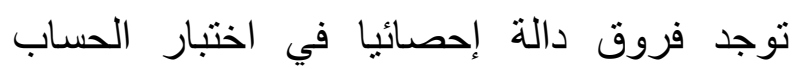

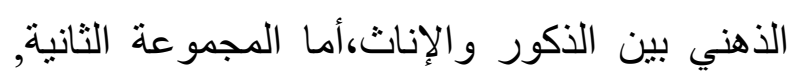

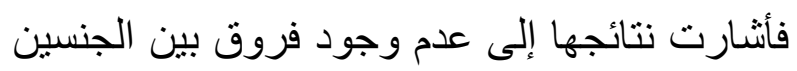

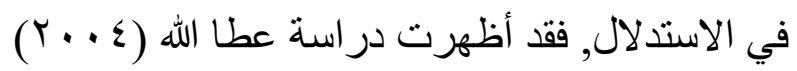

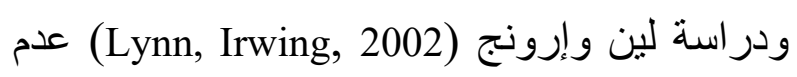
وجود فروق ذات دلالة بين الجنسين في الذكاء السائل ، أما الدراسة التي تقوم بها الباحثة الآن فقد

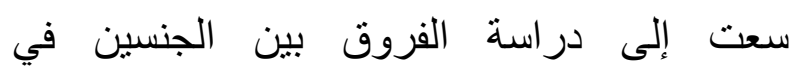

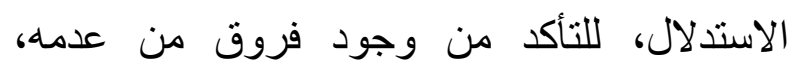
وماهى اتجاهات هذه الفروق إن وجدات

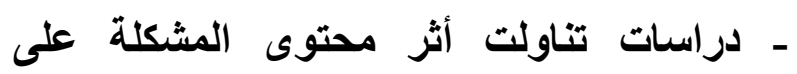
مستوى الاستدلال: - مرات

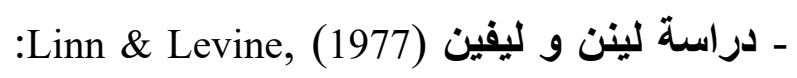
وتهدف إلى دراسة تطوير القدرة على لفين التحكم بالمتغيرات في استدلال المر اهقين، حيث تم تطبيق لفيق

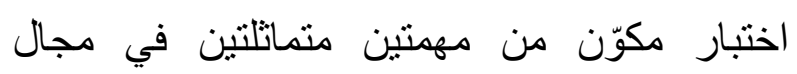

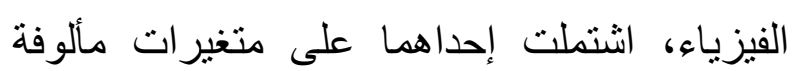

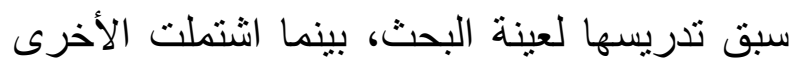

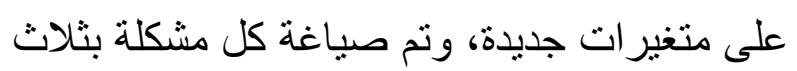
صياغات مختلفة".، وأُجري الاختبار على عيلى عينة

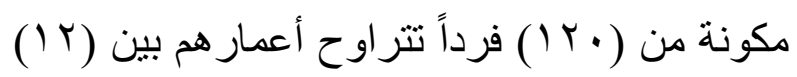

التقدير الحسابي أفضل من أداء الإناث، بينما لم

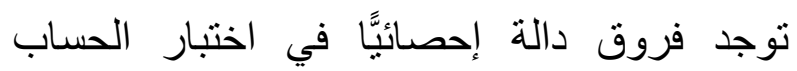
الذهني بين الذكور و الإناث. دراسة كلسوم وآخرين (Kalsoom, et al, 2012): هدفت هذه الدراسة إلى تقييم الاستدلال الخُلقي أو ما

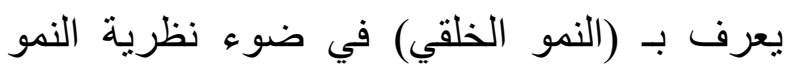

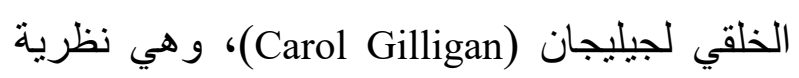

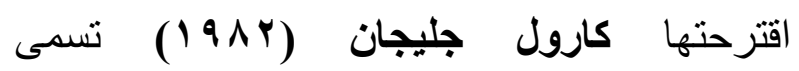

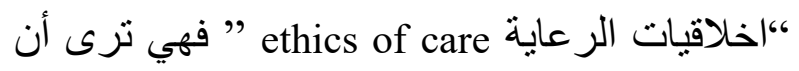

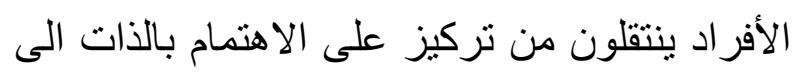

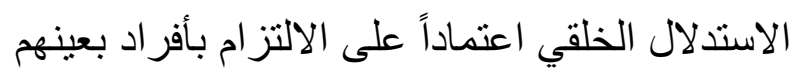

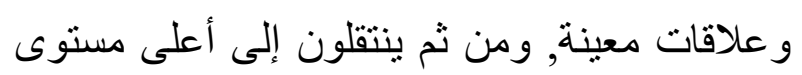

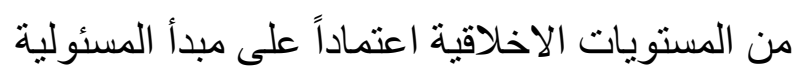

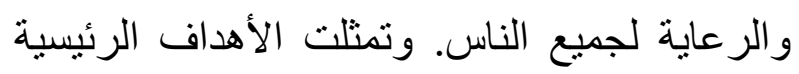

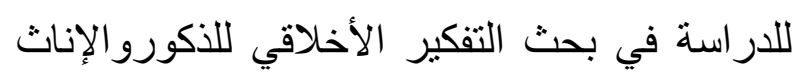

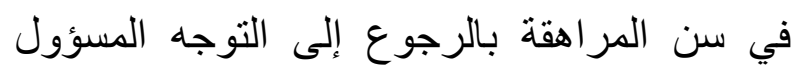

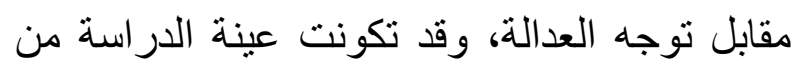

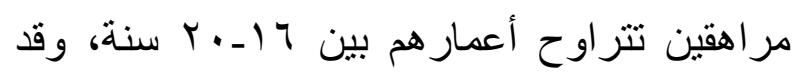

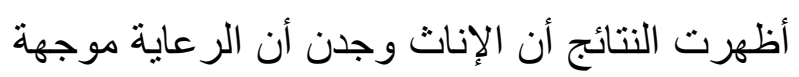

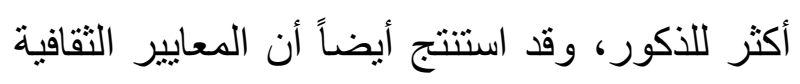

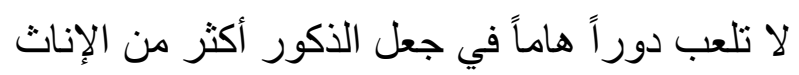

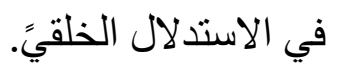

\section{تعقيب}

فيما يتعلق بالدراسات التي تناولت الفروق بين

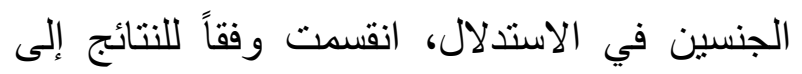

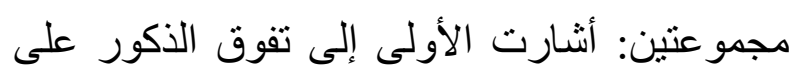

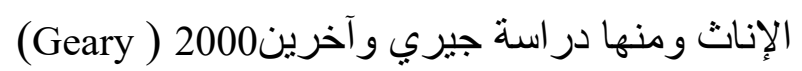


المختلفة، وتؤكد النتائج على أهمية البيئة الثرية

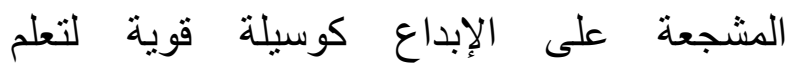

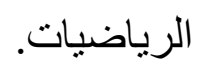

\section{تعقيب}

من خلال استعراض الدراسات التى تناولت أثنر محتوى المشكلة على مستوى الاستدلال يتبين لنا (Linn \& Levine, تأكيد نتائج در اسة لينن وليفين (1977 على أثر تضمن المشكلة لمتغيرات مألوفة

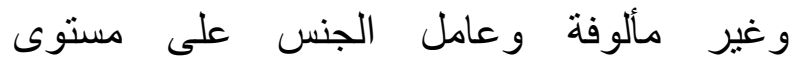

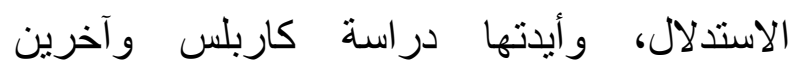
Karplus et al., (1983)

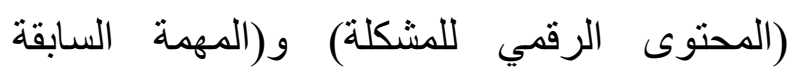
مباثرة) على الاستدلال، بينما أكدت دراسة الكة الكة المانة

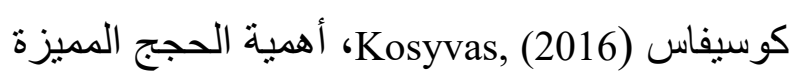

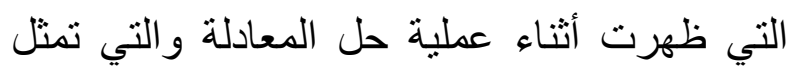

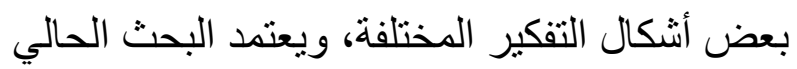

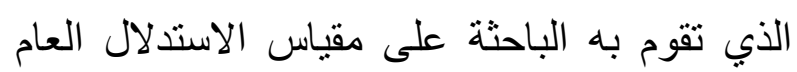
لفرنش وآخرين، وهو مقياس ذو ثلاثة أبعاد يشتمل على مشكلات حسابية بسيطة ملائمة لمستوى عينة فئن البحث.

ـ دراسات تناولت العوامل المؤثرة على مستوى

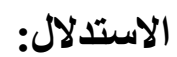

ـ Delazer et al., دراسة ديلازر وآخرين (1999) هدفت هذه الدراسة إلى بحث العلاقة بين الاستدلال الرياضي و الذاكرة الضمنية لدى فاقدي الذاكرة، وقد لوحظت آثار أولية في استرجاع الحقائق الحسابية

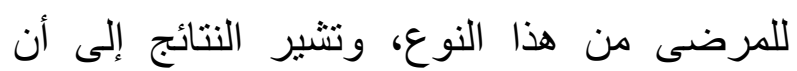
الإجابة على أول سلسلة عددية (على سبيل المثال:

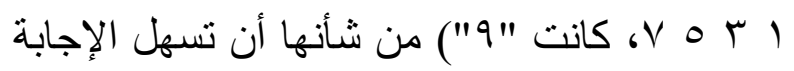

إلى (ع () سنة، وقد أظهرت النتائج ثباين نسبة

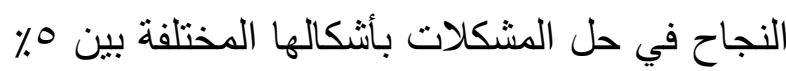

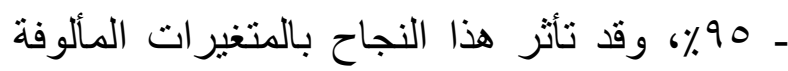

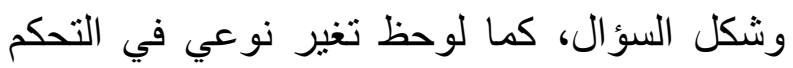

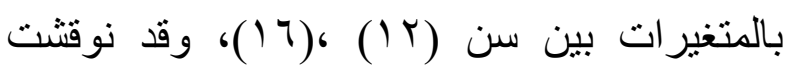

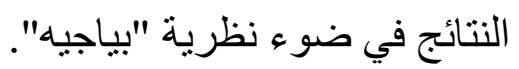

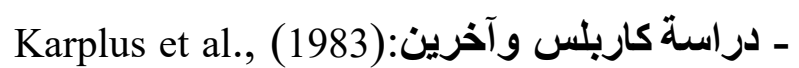
تهدف إلى دراسة الاستدلال التناسبي لدى صغار

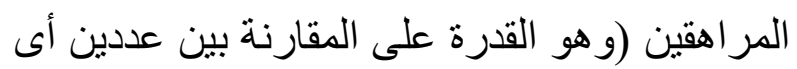
الاستدلال من خلال مفهوم النسبة والتناسب)، وقد الندارن

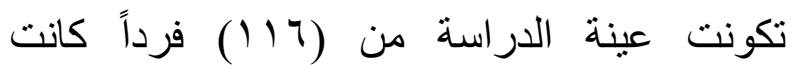

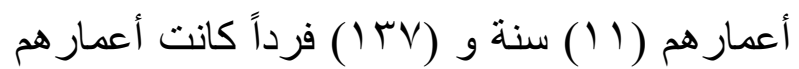

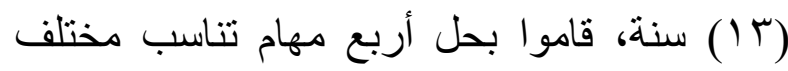
المحتويات العددية و المرجعية، ولم تُظهر النتائج أي لثي تأثير لفارق السن في حل هذه المهام، ولكنة ولكن

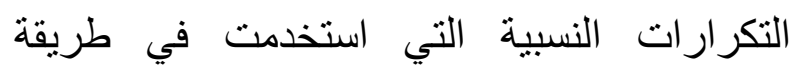

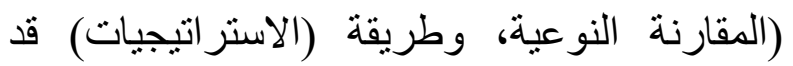

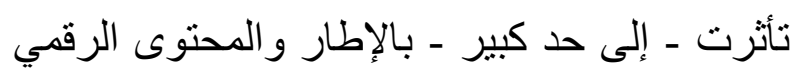
للمشكلة، وبالمهمة السابقة مباثرة. - دراسة كوسيفاس (2016) : دراسة تجريية تهدف إلى دراسة مستويات الاستدلال الحسابي في حل المشكلات الرياضية

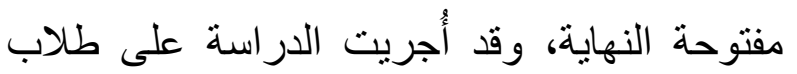

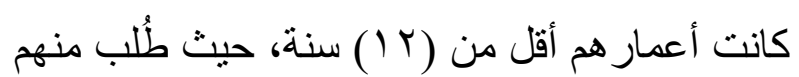

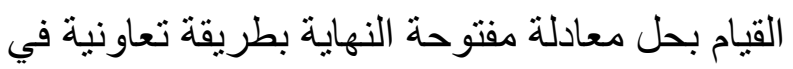
مجموعات من أربعة أفراد، عبر التشاور و النقانش

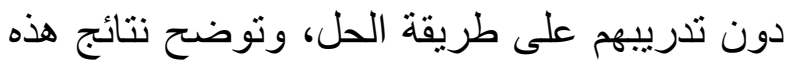
الدراسة إلى أهية الحجج المميزة التي ظهرت التهات أثناء عملية حل المعادلة والتي تمثل بعض أثنكال التفكير 
دراسة القلاف (• • (Y): و هدفها معرفة مدى أثر وحدة إثرائية في مادة الرياضيات على تنمية الاستدلال المكاني وتحسين التحصيل في الهندسة التسبة لاى تلميذات الصف الخامس الابتدائي في دولة الكئ الكويت، حيث تكونت عينة البحث من (1/ (1)

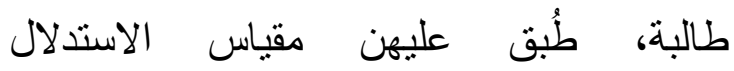

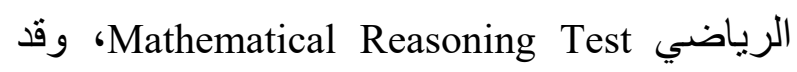
توصلت النتائج إلى أن العلاقة الارتباطية وثيقة بين

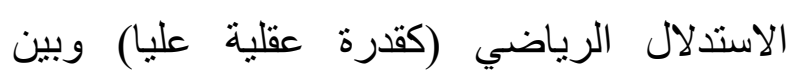
التحصيل في مادة الرياضيات.

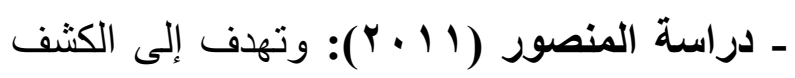

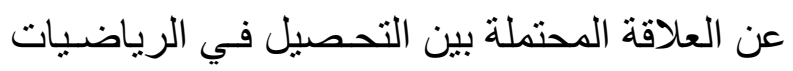

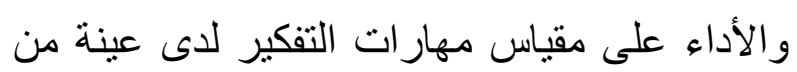

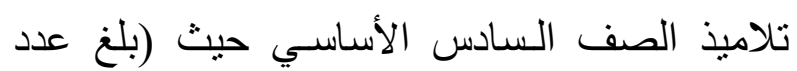

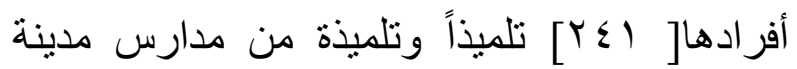
دمشق الرسمية)، وقد أنشارت النتائج إلى وجود مدارد

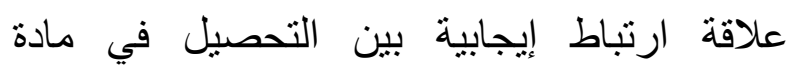

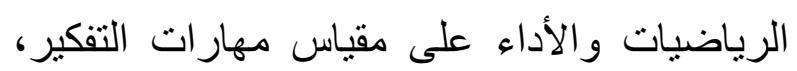

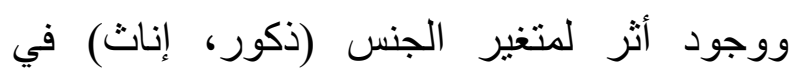

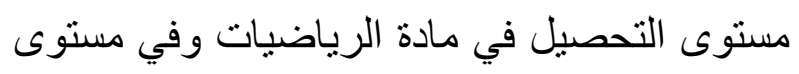

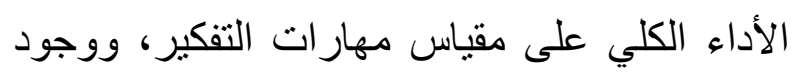

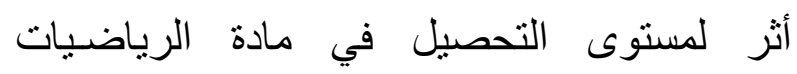

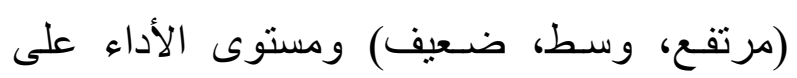
مقياس مهار ات التفكير.

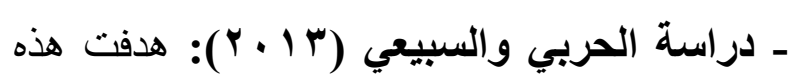

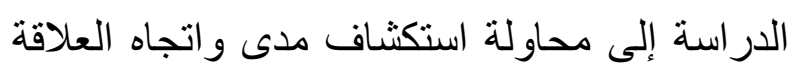

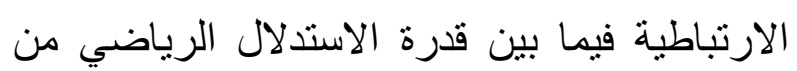

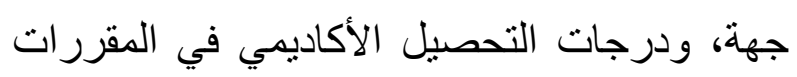
الدراسية الدختلفة، وفي مقدمتها الرياضيات. تكونت التهرئ
على السلسلة العددية الثانية (r ع Y A A، الجواب

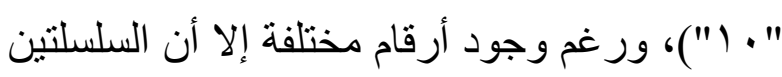
كلتيهما تتقاسمان نفس الخو ارزمية الأساسية (Y+ (Y).

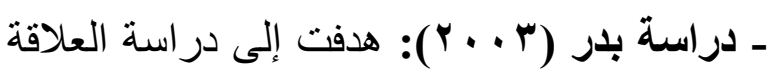
بين الاستدلال المنطقي والتحصيل في الرياضيات

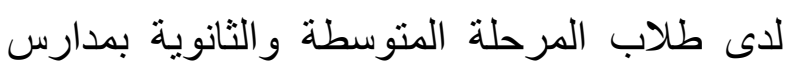

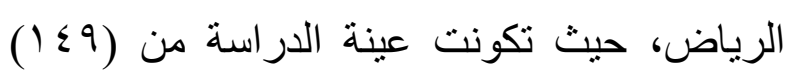

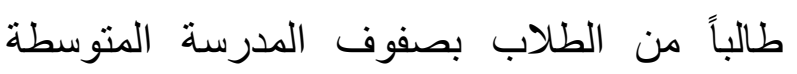
والصف الأول الثنانوي، طُبق عليهم مقاييس اختبار

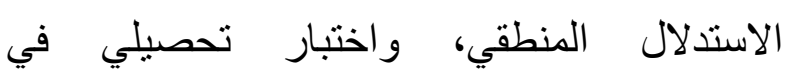
الرياضيات، وقد توصلت نتائج الدراسة إلى وجود الإدي علاقة ارتباطية بين التحصيل في مادة الرياضيات

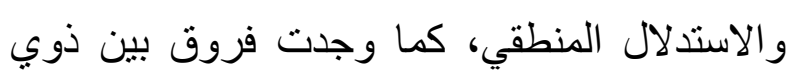

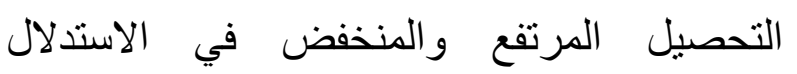
المنطقي.

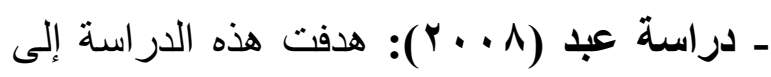

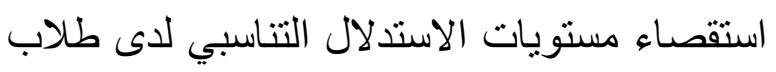

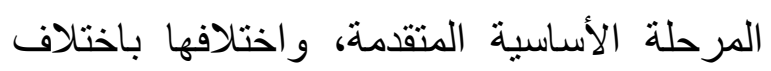

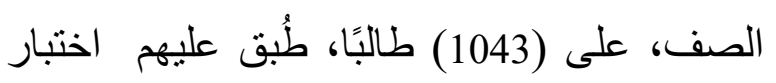

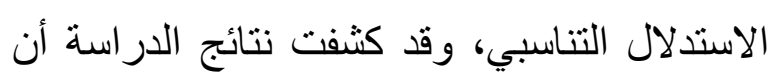

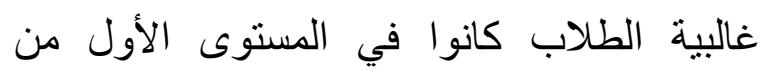

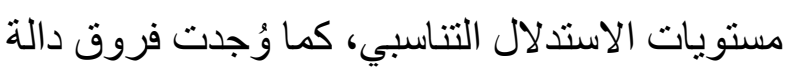
إحصائياً في مستويات الاستدلال التناسبي تبعًا

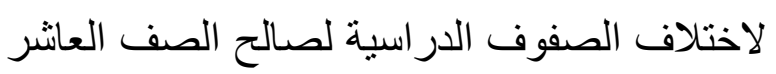
الأساسي، وأن هذه المستويات تتمو نوعًا ما طردياً

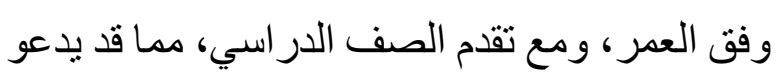

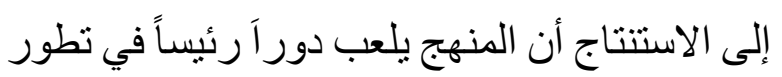
هذه المستويات. 
الاستدلال كعملية مهمة في تعلمهم و إدراكهم، وتتكون هذه الدراسة من جزئين الأول يتحقق من فهنه دور الفروق الفردية في الاستدلال عبر أربعة هندة النية أشكال، و الثاني يحدد عمليات الاستدلال المتتابعة وأثر الفروق الفردية فيها، وتثير النتائج إلى واتى انخفاض أداء الطلاب نتيجة صعوبات خاصة في وني تحديد الاستنتاجات ذات الصلة وفي رسم تللك الاستنتاجات، ويرجع ذللك في بعضه إلى العلاقة بين

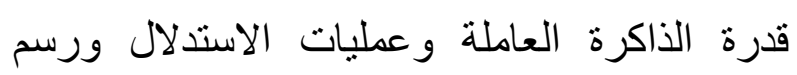
الخر ائط.

\section{تعقبب:}

تناولت الدراسات السابقة بعض العوامل المؤثرة على القدرة على الاستدلال ومنها المرحلة العمرية أو عامل السن أو الصف الدر اسي ورأت أن لله تأثير على تلك القدرة، ومنها دراسة ديلازر وآخرين،

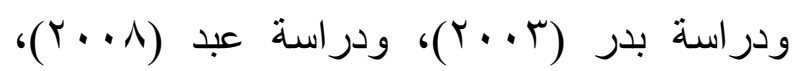
و إلى أي تأثثير لفارق السن في الاستدلال على حل

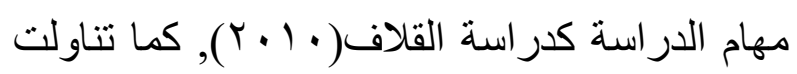
بعض الدراسات العلاقة بين مستوى الاستدلال وبعض القدرات و العوامل الذاتية ومنها در اسة عبد (ب.^) و التقييم الذاتي، والتعبير عن الذات) ، ودراسة

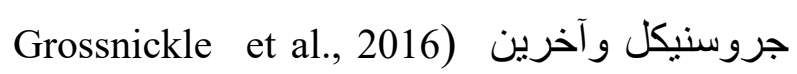
)عن (قدرة الذاكرة العاملة وعمليات الاستدلال ورسم الخرائط), على حين اكتفت الدراسة الحالية بدر اسة الاستدلال لاى تلامبذ الصف السادس من حن

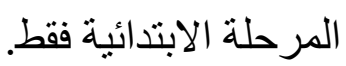
ـ دراسات تناولت برامج تنمية الاستدلال:
عينة الدر اسة من (7 ) طالباً من الطلاب الذكور

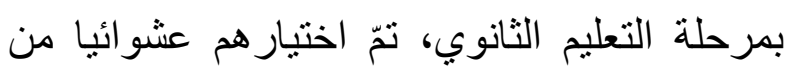
المدارس الثانوية بدولة الكويت للصف الثاني عثر عند القسم العلمي. وقد توصلت الدراسة إلى أن عوامل التفوق الأكاديمي ليست هي القدرات المعرفية وحدها بالنسبة للطالب المتفوق وإنما هنالك أيضاً أساليب تعلم ومهار ات ونظم خاصة يتبعها الطالب المتفوق في تحصيله الأكاديمي منها التوازن فيما

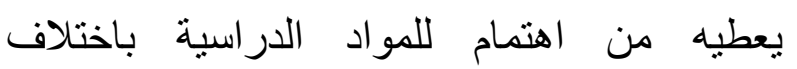
مضامينها، وحسن تتظيم الوقت وكفاءة توزيع هذه الهن الطاقة بطريقة عادلة في بذل الجهد التعليمي و العقلي

$$
\text { على السواء. }
$$

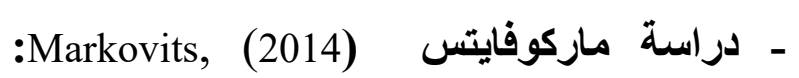
تهدف هذه الدراسة إلى فهم تطور الاستدلال الشرطي، من خلال اختبار الفرضية القائلة بأن هناك مرحلة نمائية انتقالية بين الاستدلال الثرطي

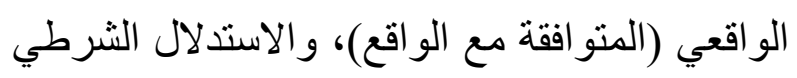
السببي( المخالفة للواقع) ، حيث تلقى (هبه (لوه) طالباً

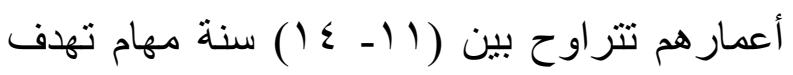
إلى تشجيع استخدام المشاكل الاستدلالية باستخدام

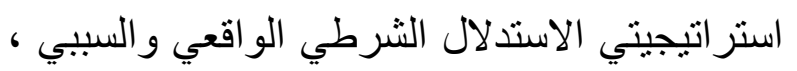

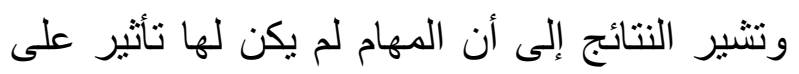

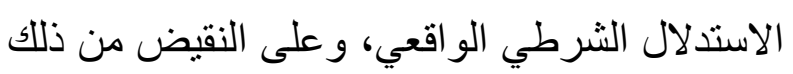
فإن المهام للاستدلال الشرطي السببي قد أحدثت تحسناً كبير في الاستدلال المنطقي، خاصة لاى الطلاب الأصغر سناً. et al., دراسة جروسنيكل وآخرون عنئ (2016) Grossnickle قرة طلاب المرحلة الجامعية على تمييز أنماط هده 
الرياضيات المتقدة الإيجابي في تطوير مهارات التفكير العامة بما فيها الاستدلال.

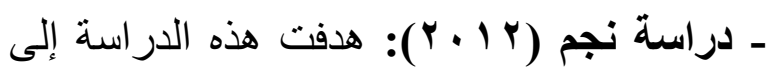
الكثف عن أثر برنامج تدريبي مقتر ح لتنمية التفكير

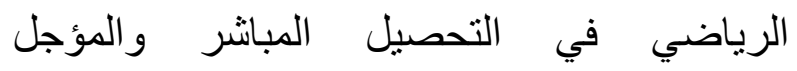
(الاحتفاظ) في الرياضيات، وقد تكونت عينة

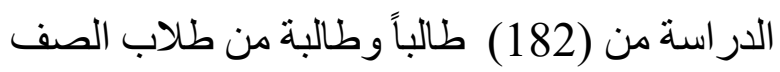

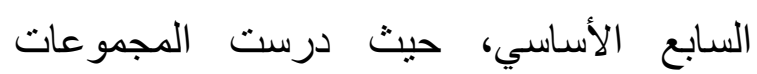
التجريبية البرنامج التدريبي الذي هدف التيف إلى تتمية

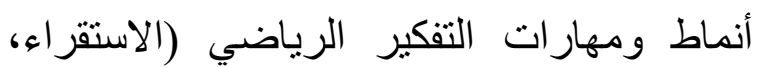

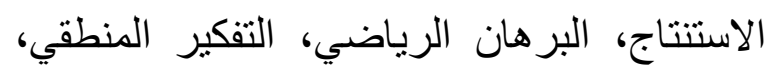

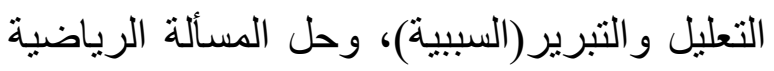

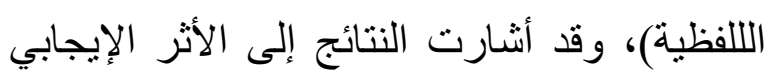
لبرنامج تنمية التفكير الرياضي في تحسين التحصيل التئري

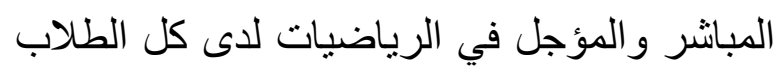
من (الذكور و الإناث)، وتفوقه في ذللك على الطريقة التقليدية في التدريس.

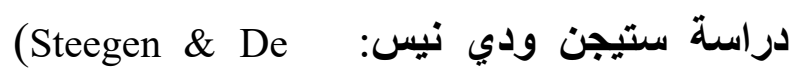

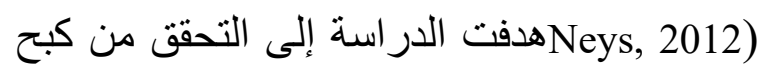
الاعتقاد غير المنطقي لدى المر اهقين الذين تتراوح

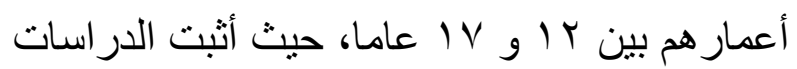

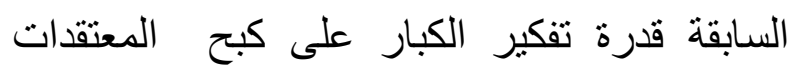

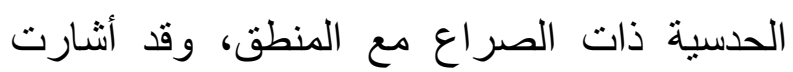
النتائج إلى ضعف تذكر الكلمات التي ترتبط التبط بالمعتقدات المضللة و التي نم تلقينها أثناء التفكير لتربات

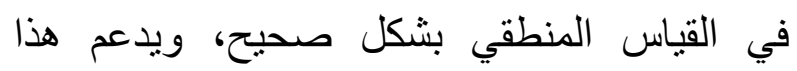
الاستنتاج أنه حتى لدى المراهقين الأصغر سناً يتوسط كبح الاعتقاد غير المنطقي التفكير الصحيح طالما أنه في صر اع مع الاعت عير الاعتبار ات المنطقية.

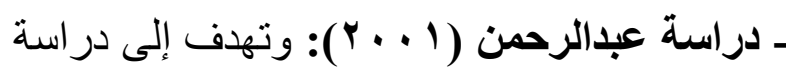
فاعلية وحدة مقترحة في المنطق الرياضي علي ألداء

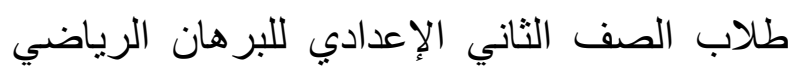

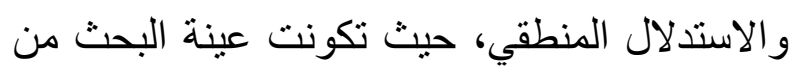

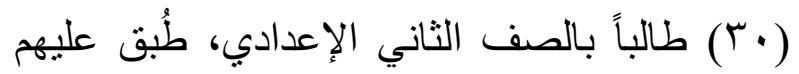
مقياس البرهان الرياضي، ومقياس الاستدلال

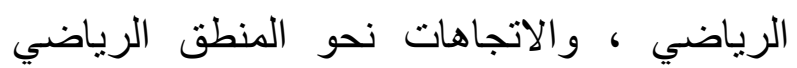

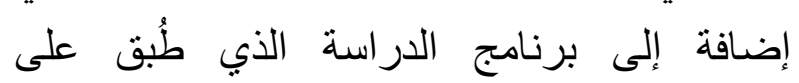
المجمو عة التجريبية، وقد توصلت النتائج إلى فاعلية البرنامج في تنمية التحصيل في المنطق و البرهان

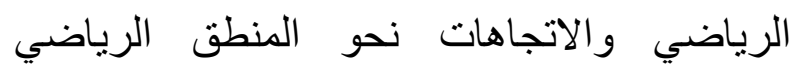
و الاستدلال المنطقي.

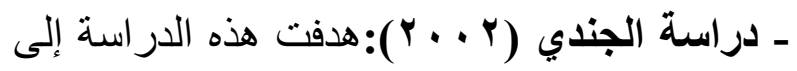

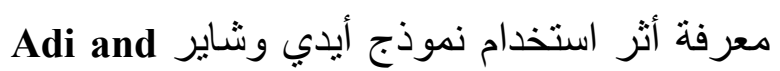
Shire cognitive growth acceleration model في تسريع النمو المعرفي وتنمية التفكير الاستدلالي و التفكير الناقد على تحسين تحصيل طالبات الصف

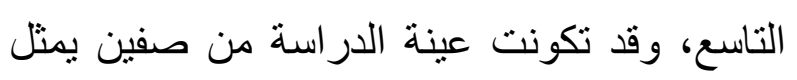

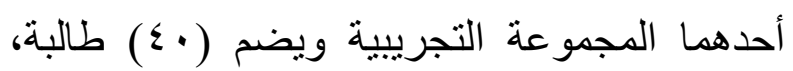

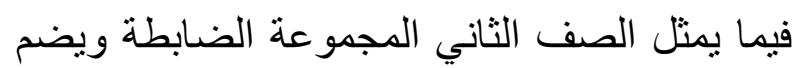

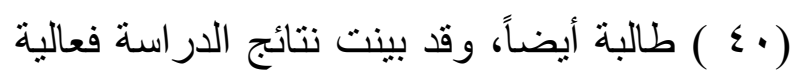

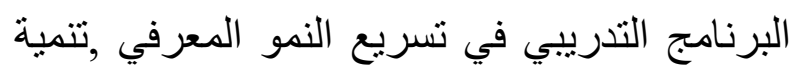
التفكير الاستدلالي و الناقد.

(Inglis\& Simpson, دراسة إنظليس وسيمبسون ولالأل (2008: تهدف إلى دراسة دور الرياضيات المتقدمة

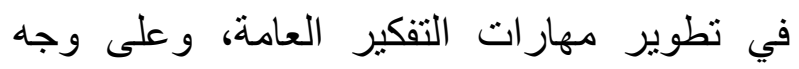

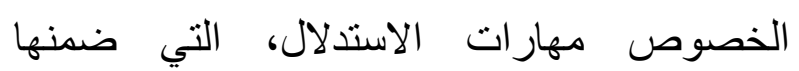
theory of formal الباحثان في نظريتهما discipline" 
دراسة السعيد (T/ • ب) بتنمية الاستدلال باستخدام

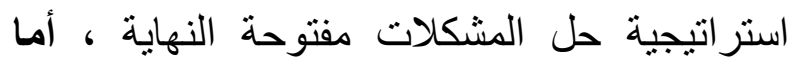
Steegen \& De دراسة ستيجن ودي نيس حلنهن فقد أشارت نتائجها إلى ضعف Neys, (2012) تذكر الكلمات التي ترتبط بالمعتقدات المضللة و التي تم تلقينها أثناء التفكير في القياس المنطقي بثكل صحيح، كما أظهرت أنه حتى لدى المر اهقين الأصغر سناً يكبح الاعتقاد غير المنطقي التفكير الصحيح طالما أنه في صراع الاع مع الاعتبار ات المنطقية.

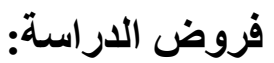

في ضوء ماسبق يمكن التعبير عن فروض الدراسة فيما يلي: ـ الاستدلال العام و أبعاده الفرعية ذو مستوى متوسط لدى تلاميذ الصف السادس الإبتدائي من(العينة الكلية). ـ ـ الاستدلال العام و أبعاده الفرعية ذو مستوى . متوسط لدى تلاميذ الصف السادس الإبتدائي من(عينة الإناث).

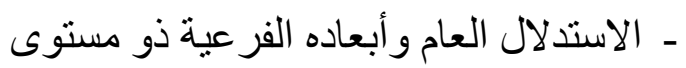
متوسط لدى تلاميذ الصف السادس الإبتدائي من(عينة الذكور). - توجد فروق دالة إحصائياً عند مستوى دلالة I., ب بين متوسطات درجات تلاميذ المرحلة الإبتدائية الذكور و الإناث في الاستدلال العام و أبعاده

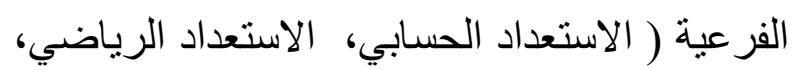
و العمليات الحسابية) لصالح الذكور. - يتصف نموذج العلاقات بين متغيرات الدراسة لدى تلاميذ الصف السادس الابتدائي بالملاءمة

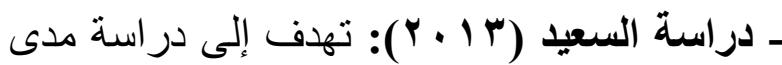
فاعلية استخدام استراتيجية حل المشكلات مفتوحة النهاية في تنمية مهار ات الاستدلال الرياضي لدى طالبات المرحلة المتوسطة، حيث تكونت عينة الار اسة من مجمو عتين إحداهما تجريبية و الأخرى ضابطة، طُبق عليهما مقياس مهار ات الاستدلال

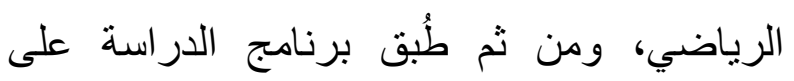

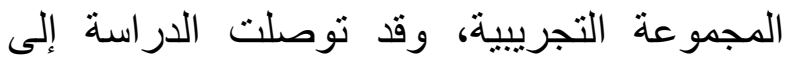
فاعلية البرنامج في تتمية مهارات الاستدلال الرياضي لاى طلاب المرحلة المتوسطة. تعقيب:

فيما يتعلق بالدر اسات السابقة عن مدى فاعلية بر امج

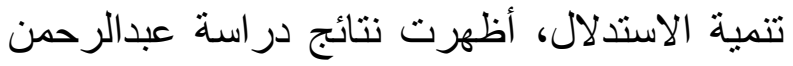

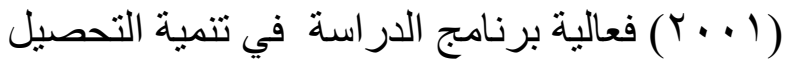
في المنطق والبرهان الرياضي والاتجاهات نحو المنطق الرياضي والاستدلال المنطقي، كما أظهرت

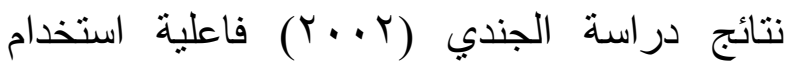
نموذج أيدي وشاير في تسريع النمو المعرفي وتنمية

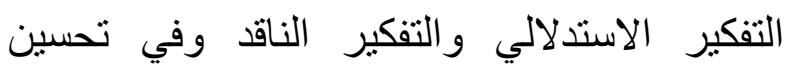
تحصيل طالبات الصف التاسع، ودراسة إنغليس ولئ وسيمبسون Inglis\& Simpson, (2008) توصلت نتائجها إلى دور الرياضيات المتقدمة الفاعل في تطوير مهار ات التفكير العامة ومنها

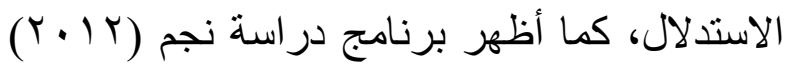
فاعلية في تتمية أنماط ومهار ات التفكير الرياضي دهاي المتمثل في (الاستقراء، الاستنتاج، البرهئ

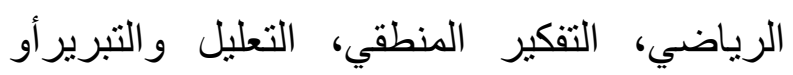
السببية)، وحل المسألة الرياضية اللفظية، كما قامت 


\section{العينة الاستطلاعية:}

أن الهدف من الدراسة الاستطلاعية مساعدة الباحثة

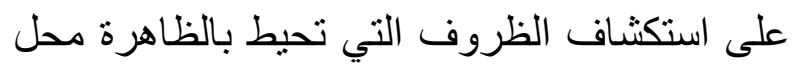
الاراسة، لفهم العقبات و الصعوبات التي تقف أمام

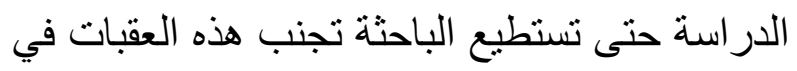
الدراسة الأساسية وتحديد الخصائص السيكومترية الباسية لدقاييس الدراسة شملت عينة الدراسة الاستطلاعية

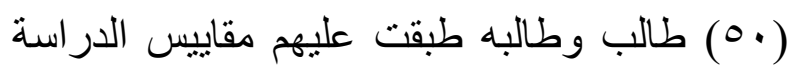

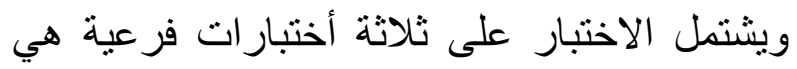
الاستعداد الحسابي Arithmatic Aptitude Test واختبار الاستعداد الرياضي Mathematics الحسبة Aptitude Test

الحسابية Necessary Arithmatic Operation .Test الأساليب الاحصائية:

تم تحليل بيانات الدر اسة لاختبار صحة الفروض الأبل بإجراء اختبار "ت"، "T" student test "لتحديد الفروق بين الذكور والإناث, وتحليل الانحدار Regression analysis الاحصائية للنموذج.

أدوات الاراسة: مقياس الاستدلال العام (س ع) :RG Reasoning General وهو أحد اختبارات الاستدلال ببطارية الاختبارات العاملية المعرفية إعداد أكستروم، فرنش، و هارمان، وديرمين Ekstrom, French, Harman, (Dermen, 1976)، ترجمة الثيخ و وآخرين (لائن (1997)، ويشتمل الاختبار على ثلاثة أختبارات

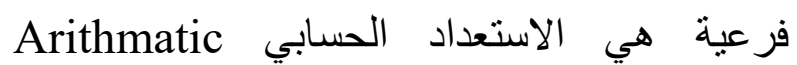
Aptitude Test
الإحصائية لبيانات التلاميذ، كما تعكسها مؤشرات

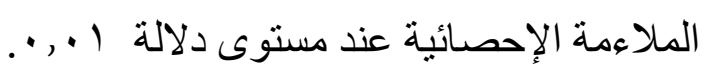
منهج الاراسة:

اتبعت الباحثة في هذه الدراسة المنهج الوصفي التحليلي المقارن، لبيان مستوى الاستدلال العام وأبعاده الفرعية لاى تلاميذ المرحلة الإبندائية من الإن

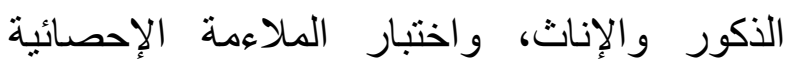
للعلاقة بين المكونات المعّرفة للاستدلال، ويقوم هذار الإنا المنهج على وصف الظاهرة للوصول إلى أسبابها

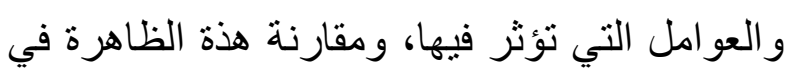
عينات مختلفة، واستخلاص النتائج لتعميمها.

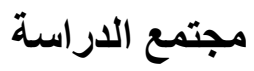

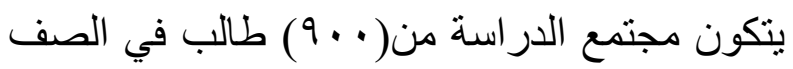

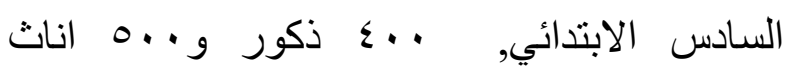

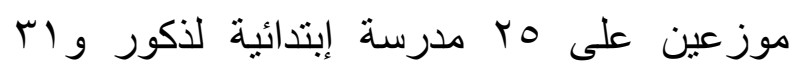

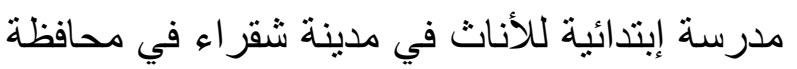
شقراء وفق أحصاءات ادارة التعليم بمحافظة شقر اء. - ماء

\section{عينة الدراسة:}

اختارت الباحثة عينة عشوائية من مجتمع لرالية

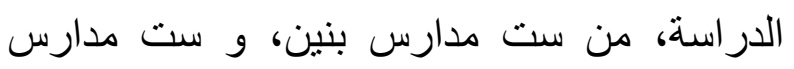

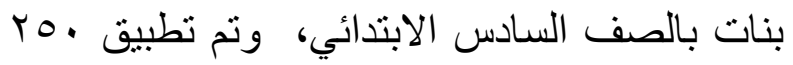
استمارة لقياس الاستدلال .حيث تم استبعاد 77

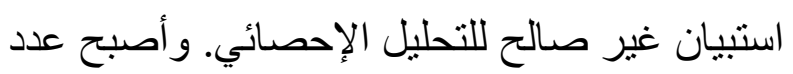

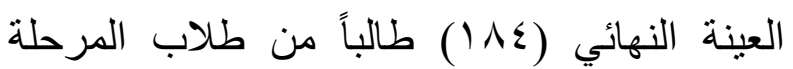

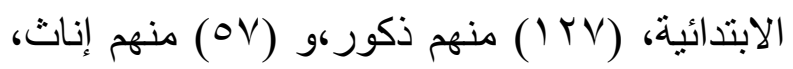

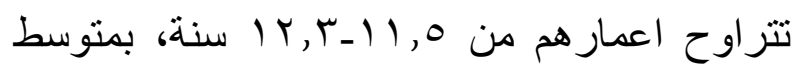

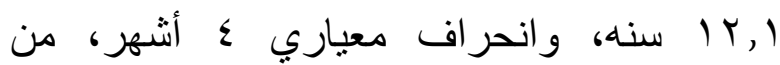

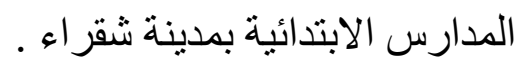


منها من (0؛) مفردة، ويوضح جدول (1) أقسام الرياضي Mathematics Aptitude Test و عدد مفردات كل منها.

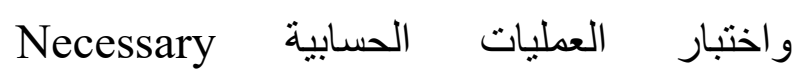
Arithmatic Operation Test

\begin{tabular}{|c|c|}
\hline أقسام ومفردات البعد الفرعي & الأبعاد \\
\hline يتكون من قسمين: القسم الأول (0 ا مفردة) ، القسم الثاني ( • مفردة) & الاستعداد الحسابي \\
\hline يتكون من قسمين: القسم الأول (ه ا مفردة) ، القسم الثاني ( • مفردة) & الاستعداد الرياضي \\
\hline يتكون من قسمين: القسم الأول (0 ا مفردة) ، القسم الثاني (· مفردة) & العمليات الحسابية \\
\hline 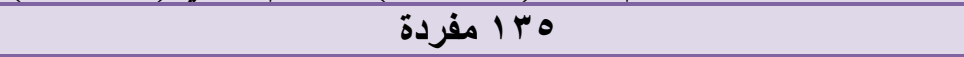 & المقياس الكلي \\
\hline
\end{tabular}

الثبات بطريقة جتمان 99 7. . . و العمليات الحسابية الثبات بطريقة جتمان بر اون بكان , •. طريقة تصحيح الاختبارات، تعطى درجتان على إنى

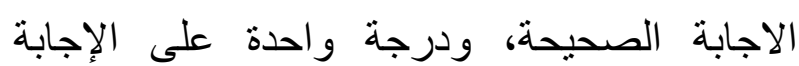
الخاطئة.

ـ التحقق من صدق وثبات مقياس الاستدلال العام

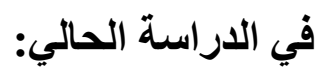
اـ صدق المحك: قامت الباحثة بالتحقق من صدق البق المحك لمقياس الاستدلال العام بحساب معاملات الارتباط بين مقياس الاستدلال العام، والإل الإنتبار

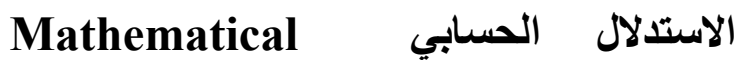
واختبار وكسلر للأكاء Wechsler Intelligence Scale

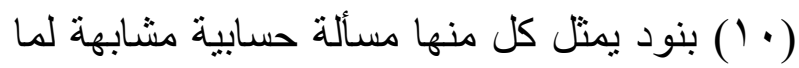
يدرس في المرحلة الابتدائية وتعد هذه المسائل شفهية ولا ينطلب حلها استخدام ورقه وقلم وتقوم

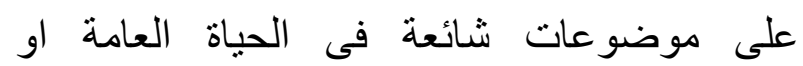
الممارسات العملية، ويوضح جدول (؟ئعة في النتائج.
التحقق من صدق وثبات مقياس الاستدلال العام: قام المؤلفون بالتحقق من الخصائص السيكومترية للمقياس من حيث الصدق والثبات، خلال تطبيقه

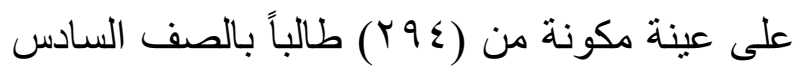

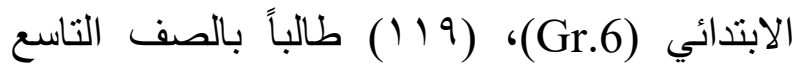

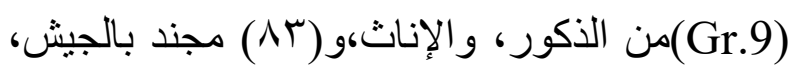

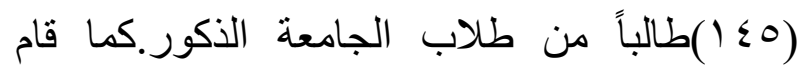
معربوا الاختبار (الثيخ، عبد السلام، والثرقاوي،

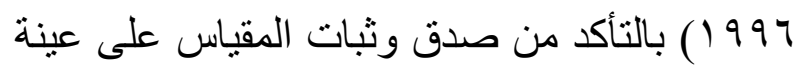

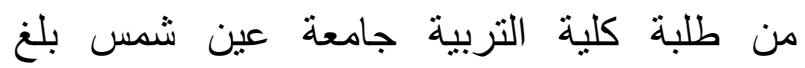

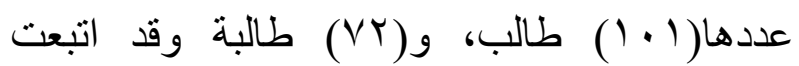

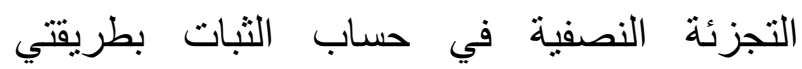

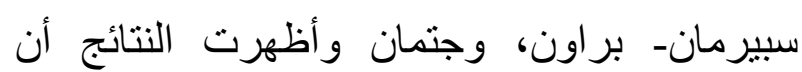
معاملات ثبات اختبار ات الاستدلال العام على النحو

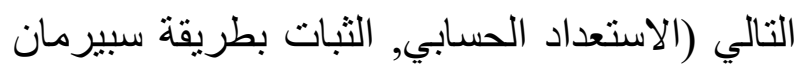
براونץ؟ , •.و الاستعداد الرياضي الثبات بطريقة

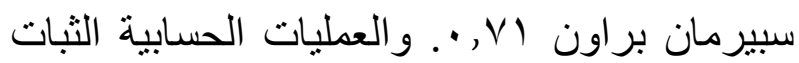
بطريقة سبيرمان بر اون ان ه • ) (الاستعداد الحسابي,

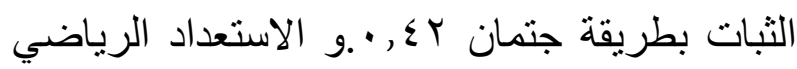

جدول (ץ) معاملات الارتباط بين مقياس الاستدلال العام واختبار الاستدلال الحسابي باختبار وكسلر للأكاء (صدق المحك) 


\begin{tabular}{|c|c|}
\hline قيمة معامل الارتباط "ر" & المحك \\
\hline$* *, \wedge \bullet$ & اختبار الاستـلال الحسابي باختبار وكسلر للأكاء \\
\hline
\end{tabular}

و الدرجة الكلية على مقياس الاستدلال العام دالة عند (1)

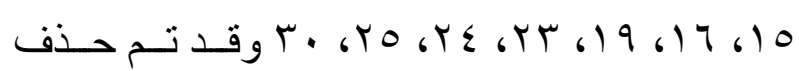
هذة المفردات ثثم حسـاب معساملات ارتبـاط مفردات

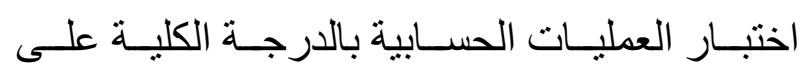

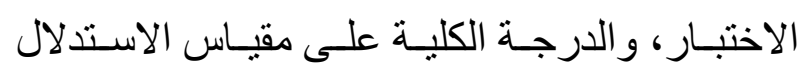
العام، كمـا أظهرت أن معـاملات الارتبـاط بين معـاملات

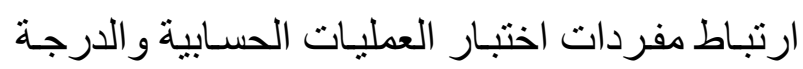

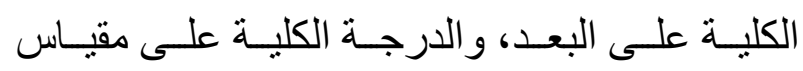

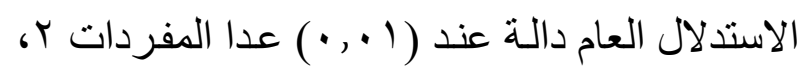
ع، 0،

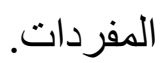
كما أن الدلالة الاحصائية لمعاملات الارتباط بين جميع الأبعاد الفرعية لمقياس الاستدلال العام و الدرجة الكلية للمقياس عند مستوى دلالة (0.01) ، وبذلك تم التحقق من صدق الاتساق الداخلي لمقياس الاستدلال العام على مستوى أبعاده الفرعية. ـ التحقق من ثبات مقياس الاستدلال العام :

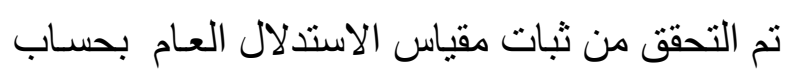

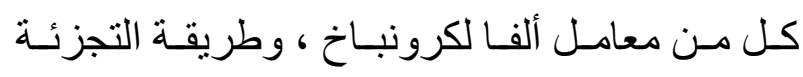

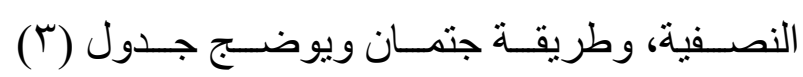
النتائج.
يتضح من خلال جدول (Y) دلالة معاملات الارتباط بين مقياس الاستدلال العام, ومحكه عند مستوى دلالة 0.01 مما بعني التأكد من صدق ومنام المحك بالنسبة لهذا المقياس. r ـ صدق الاتسـاق الداخلي: قامت الباحثنة بـالتحقق لـانق من صدق الاتسـاق الداخلي لمقياس الاستدلال العـام

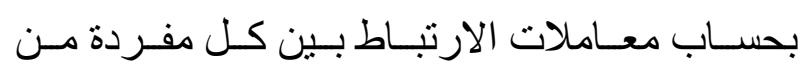

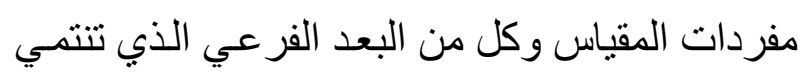

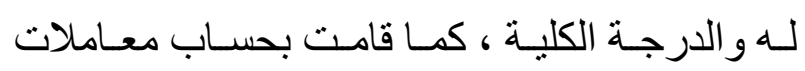

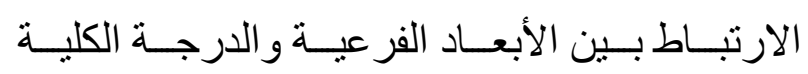

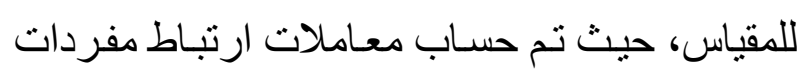

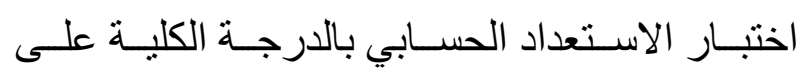

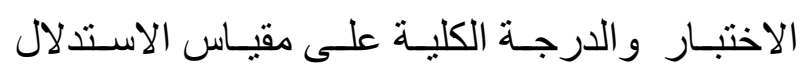

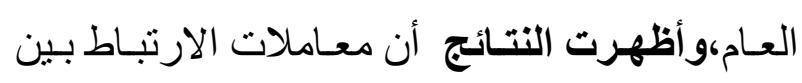
معاملات ارتباط مفردات اختبار الاستعداد الحسـيابي

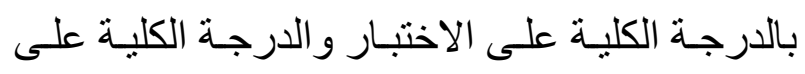

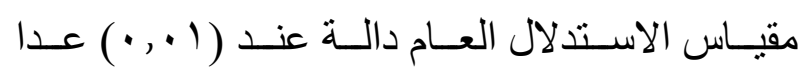

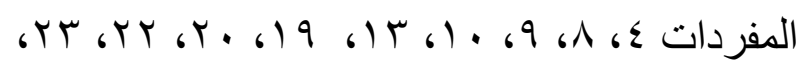

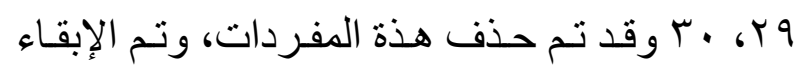

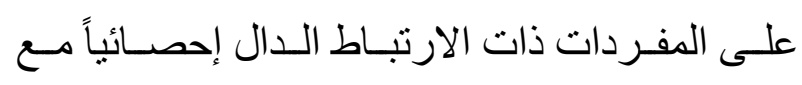
الاختبار الفرعي والاختبار الكلي.

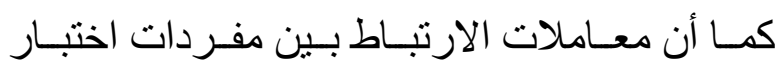

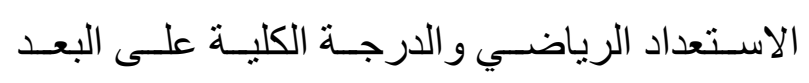

جدول (r) يوضح معاملات ثبات مقياس الاستدلال العام

\begin{tabular}{|l|l|l|l|}
\hline المقياس & معامل ألفانة النصائة & \\
\hline
\end{tabular}




\begin{tabular}{|c|c|c|c|}
\hline 0.749 & & 0.796 & الاستعداد الحسابي \\
\hline 0.291 & 0.250 & 0.306 & الاستعداد الرياضي \\
\hline 0.469 & 0.393 & 0.491 & العمليات الحسابية \\
\hline 0.779 & & 0.792 & مقياس الاستدلال العام \\
\hline
\end{tabular}

ـ الاستدلال العام وأبعاده الفرعية ذات مستوى متوسط لاى تلاميذ الصف السادس الإبتدائي (العينة الكلية من الأكور والإناث), للتحقق من من ملاديط صحة هذا الفرض قامت الباحثة بحساب النسب المئوية للمتوسطات وتحديد مستو اها، طبقاً للمعايير

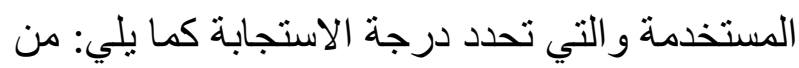

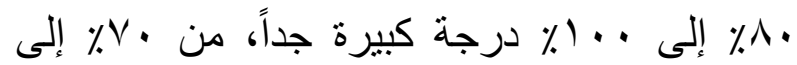

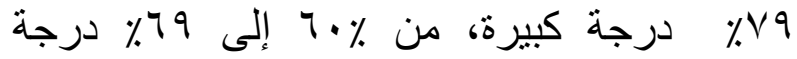
متوسطة، من •0\% إلى 9\%٪ درجة منخفضة، أقل

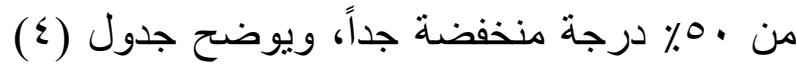

من جدول (ץ) يتضح ارتفاع مستوى ثبات المقياس و اختبار اته الفرعية في جميع طرق حساب الثبات السابقة، مما يعني التأكد من ثبات المقياس والاعتماد على استدلالاته ونتائجه في الإجابة على أسئلة الدر اسة. نتائج الدراسة: فيما يلي تعرض الباحثة كيفية التحقق من فروض الار اسة، وتفسير النتائج، وطرح التوصيات المقترحة. التحقق من صحة الفرض الأول الأي

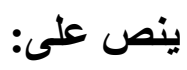
النتائج.

جدول (؛) مستويات الاستدلال العام وأبعاده الفرعية لدى طلاب الصف السادس الابتدائي(العينة الكلية)

\begin{tabular}{|c|c|c|c|c|c|}
\hline المتوسطة & المئوينة & التباين & المعياري الانحراف & المتوسط & المؤشر \\
\hline متوسط & $\% 64$ & 13.548 & 3.68078 & 21.7826 & الاستعداد الحسابي \\
\hline متوسط & $\% 60$ & 4.311 & 2.07623 & 23.7228 & الاستعداد الرياضي \\
\hline متوسط & $\% 62$ & 7.577 & 2.75265 & 27.3641 & العمليات الحسابية \\
\hline متوسط & $\% 62$ & 47.436 & 6.88741 & 72.8696 & الاستدلال العام \\
\hline
\end{tabular}

متوسط العمليات الحسابية إ جr, rV ، بنسبة مئوية ب7\% من الدرجة الكلية للمقياس الفرعي، كما بلغت

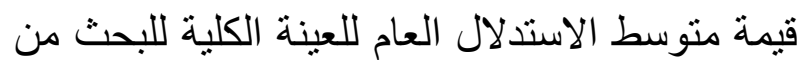
الذكور و الإناث بلغت 72.8696، بنسبة مئوية ب7\% من الدرجة الكلية لمقياس الاستدلال العام. ويفسر ذلك في ضوء اهتمام أولياء أمور التلاميذ

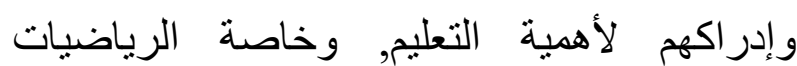

يتضح من جدول (ع) أن مستويات الاستدلال العام وجميع أبعاده الفرعية لدى عينة البحث ذات درجة متوسطة، حيث بلغت قيمة متوسط الاستعداد

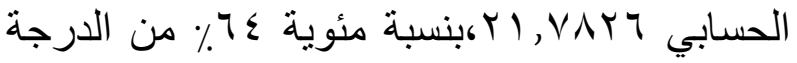
الكلية لهذا المقياس الفرعي، بينما بلغ متوسط من لهابه الاستعداد الرياضي 23.7228، بنسبة مئوية بلغت • ^\% من درجة المقياس الفرعي، كما بلغت قيمة 
ويلاحظ أن درجة مستوى الاستدلال لم تأت عالية

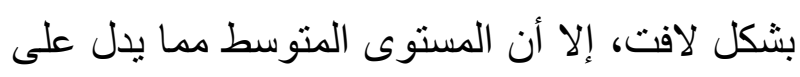

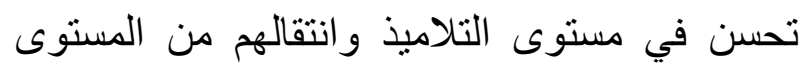
المنخفض إلى المتوسط، حيث أنشارت عديد من الدراسات السابقة إلى انخفاض مستوى الاستدلال

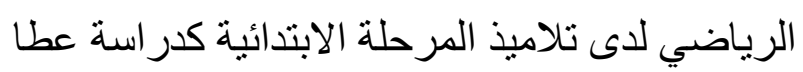

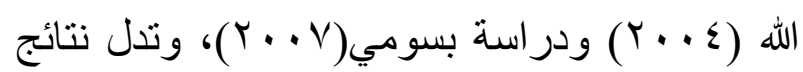

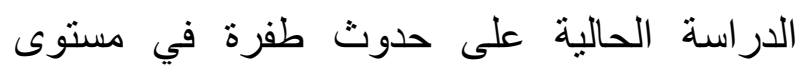

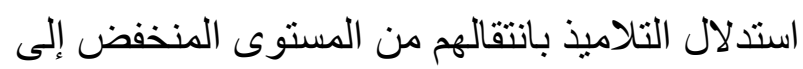

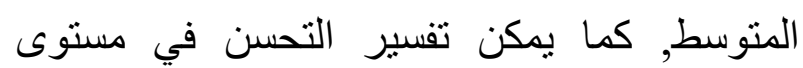
استدلال التلاميذ إلى دور الألعاب الالكترونية التي في فئ فئي

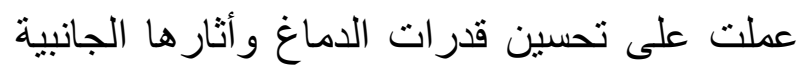
الايجابية عليهم.

التحقق من صحة الفرض الثاني والذي ينص على: - الاستدلال العام وأبعاده الفرعية ذات مستوى متوسط لاى تلميذات الصف السادس الابتدائي

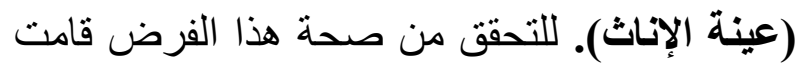
الباحثة بحساب النسب المئوية للمنوسطات وتحديد مستو اها، ويوضح جدول (0) النتائج.
و العلوم الطبيعية ودورها الواضح في تفوق التلميذ

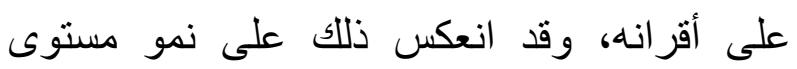
التلاميذ في الاستدلال نظراّ للعلاقة الوثيقة بين الرياضيات و العلوم الطبيعية ,والاستدلال كما أثنتته

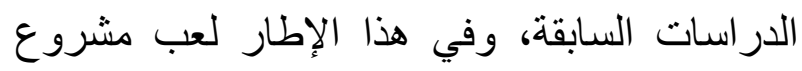
تطوير التعليم وتعلم الرياضيات المدرسية في المملكة

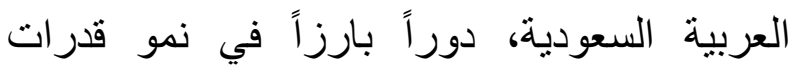

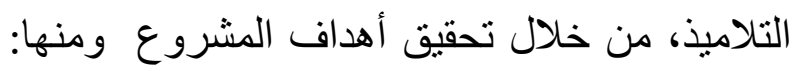

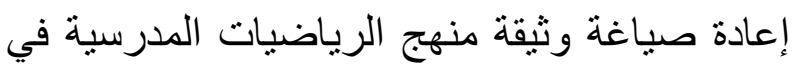
المملكة في ضوء التطورات الحديثة والتقنية، وتدريب المعلمين والمعلمات على استخدام طرق تدريس حديثة تثير التفكير لدى التلاميذ والتلميذات

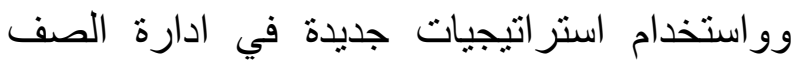
تعودهم على التعاون مثل استخدام التعلم التعاوني

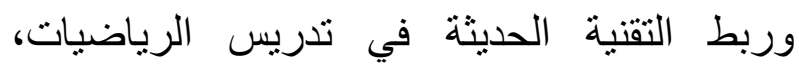
وتدريب المعلمين والمعلمات على أساليب التقويم لتصني

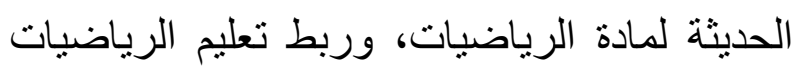
في المملكة بالمشاريع التطويرية الأخرى للتعليم مثل التل

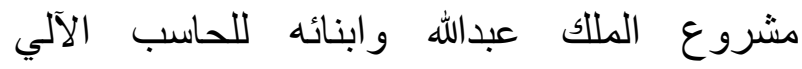
ومشروع مؤسسة الملك عبد العزيز ورجاله لرعاية الموهوبين. وكثرة المسابقات المحلية والخليجية و العالمية التي يشارك بها التلاميذ السعوديين ويفوزون بها على مستو يات متقدمة. جدول (0) يوضح مستويات الاستدلال العام وأبعاده الفرعية لاى طلاب الصف السادس الابتدائي (عينة الإناث)

\begin{tabular}{|c|c|c|c|c|c|}
\hline المتوسطة & النسبة المئوية & التباين & المعياري & المتوسط & المؤشر \\
\hline كبيرة & $73.5 \%$ & 22.964 & 4.79211 & 25.0000 & الاستعداد الحسابي \\
\hline متوسط & $61 \%$ & 6.756 & 2.59916 & 24.3158 & الاستعداد الرياضي \\
\hline متوسط & $67 \%$ & 10.643 & 3.26244 & 29.5614 & العمليات الحسابية \\
\hline متوسط & $67 \%$ & 77.824 & 8.82179 & 78.8772 & الاستدلال العام \\
\hline
\end{tabular}


كما سبق في تفسير الفرض الأول في ضوء اهنمام

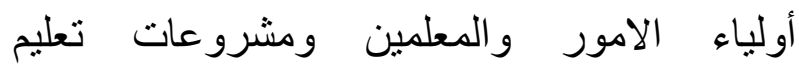

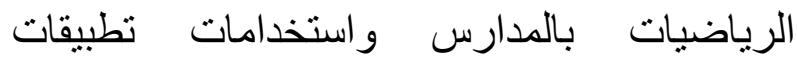
الهواتف الذكية في اثراء براهج الرياض واضيات بالإضافة إلى تبسيط وحدات مقرر الرياضيات

بصورة محببه لتلاميذ بهذه المرحلة. التحقق من صحة الفرض الثالث والأي ينص على: الاستدلال العام وأبعاده الفرعية ذات مستوى متوسط لاى تلاميذ الصف السادس الابتدائي (عينة

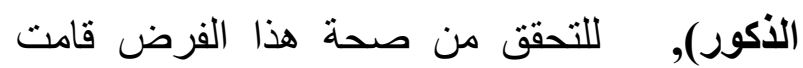
الباحثة بحساب النسب المئوية للمتوسطات وتحديد مستو اها، ويوضح جدول (7) النتائج.
يتضح من جدول (0) أن مستويات الاستدلال العام و أبعاده الفرعية لاى عينة الإناث جميعها متوسطة، عدا الاستعداد الحسابي الذي جاء مستو اه كبير ا حيث بلغت قيمة متوسطه 25.0000، بنسبة مئوية 0,\% من الدرجة الكلية للمقياس الفرعي، بينما

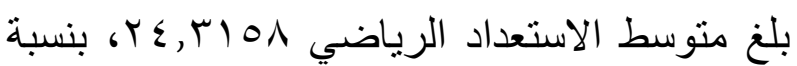
مئوية بلغت ال\% من من درجة المقياس الفرعي، كما

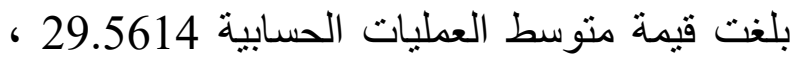
بنسبة مئوية 67\% من الدرجة الكلية للمقياس

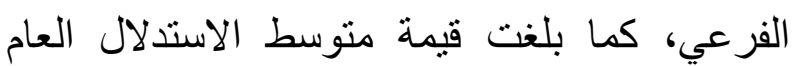
لعينة البنات 78.8772، بنسبة مئوية 67\% من

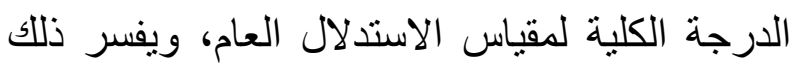

جدول (†) يوضح مستويات الاستدلال العام وأبعاده الفرعية لاى طلاب الصف السادس الابتدائي (عينة الذكور)

\begin{tabular}{|c|c|c|c|c|c|}
\hline المتوسطة درجة & المئوينة & التباين & الالمعياري & المتوسط & المؤشر \\
\hline متوسط & $60 \%$ & 2.686 & 1.63891 & 20.3386 & الاستعداد الحسابي \\
\hline متوسط & $60 \%$ & 3.028 & 1.74008 & 23.4567 & الاستعداد الرياضي \\
\hline متوسط & $61 \%$ & 3.110 & 1.76352 & 26.3780 & العمليات الحسابية \\
\hline متوسط & $60 \%$ & 10.652 & 3.26379 & 70.1732 & الاستدلال العام \\
\hline
\end{tabular}

والإناث 70.1732، بنسبة مئوية 60\% من الدرجة الكلية لمقياس الاستدلال العام، ويفسر ذلك أيضاً في

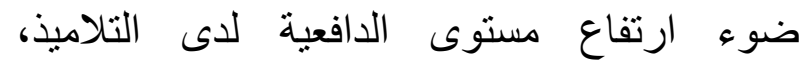
والاهتمام بالمهام الأكاديمية المستمد من اهتمام أولياء الأمور والمعلمين وتعدد مشروعات التعليم بالمدارس وكثرة المسابقات المحلية و والخليجية والعالمية التي يشارك بها بهارة التلاميذ السعوديين ويفوزون بها على مستويات متقدمة. التحقق من صحة الفرض الرابع والأي ينص على:توجد فروق دالة احصائيا عند مستوى دلالة
يتضح من جدول (†) أن مستويات الاستدلال العام وجميع أبعاده الفرعية لدى عينة الذكور متوسطة، لأنول حيث بلغت قيمة منوسط الاستعداد الحسابي 20.3386،بنسبة مئوية •ج\% من الدرجة الكلية لهذا المقياس الفرعي، بينما بلغ متوسط الاستعداد

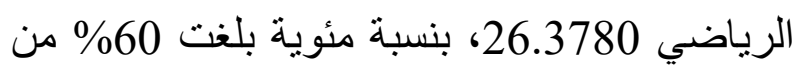
درجة المقياس الفرعي، كما بلغت قيمة متوسط العمليات الحسابية 26.3780، بنسبة مئوية 61\% من الدرجة الكلية للمقياس الفرعي، كما بلغت قيمة متوسط الاستدلال العام للعينة الكلية للبحث الذكور 
للتحقق من صحة هذا الفرض قامت الباحثة بالمقارنة بين منوسطي المجمو عتين الذكور و الإناث

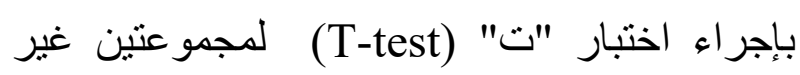

l., بين متوسطات درجات تلاميذ الصف

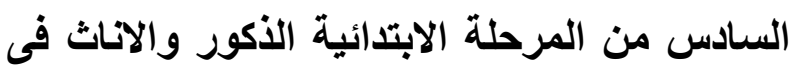
مستويات الاستدلال العام وأبعاده الفرعية . متجانستين، ويوضح جدول (V) النتائج.

جدول (V) يوضح الإحصاء الوصفي لمستويات الاستدلال العام وأبعاده الفرعية لدى الذكور والإناث

\begin{tabular}{|c|c|c|c|c|c|}
\hline متوسط الخطار & الالمعراف & المتوسط & ن & المجموعا & المتغيرات \\
\hline .63473 & 4.79211 & $\begin{array}{c}25.000 \\
0\end{array}$ & 57 & 1.00 & \multirow{2}{*}{ الاستعداد الحسابي } \\
\hline .14543 & 1.63891 & $\begin{array}{c}20.338 \\
6\end{array}$ & 127 & 2.00 & \\
\hline .34427 & 2.59916 & $\begin{array}{c}24.315 \\
8\end{array}$ & 57 & 1.00 & \multirow{2}{*}{ الاستعداد الرياضي } \\
\hline .15441 & 1.74008 & $\begin{array}{c}23.456 \\
7\end{array}$ & 127 & 2.00 & \\
\hline .43212 & 3.26244 & $\begin{array}{c}29.561 \\
4\end{array}$ & 57 & 1.00 & \multirow{2}{*}{ العمليات الحسابية } \\
\hline .15649 & 1.76352 & $\begin{array}{c}26.378 \\
0\end{array}$ & 127 & 2.00 & \\
\hline 1.16847 & 8.82179 & $\begin{array}{c}78.877 \\
2\end{array}$ & 57 & 1.00 & \multirow{2}{*}{ الاستدلال العام } \\
\hline .28961 & 3.26379 & $\begin{array}{c}70.173 \\
2\end{array}$ & 127 & 2.00 & \\
\hline
\end{tabular}

جدول (^) يوضح نتائج اختبار "ت" للفروق بين المتوسطات في مستويات الاستدلال العام وأبعاده الفرعية لدى الذكور والإناث

\begin{tabular}{|c|c|c|c|c|c|c|}
\hline الدالة & "تيمة & الدرية & متوسط الخطأ & العدد & المجموعات & المتغيرات \\
\hline \multirow[t]{2}{*}{.000} & \multirow[t]{2}{*}{9.787} & \multirow[t]{2}{*}{182} & .47631 & 57 & البنات & \multirow{2}{*}{ الاستعداد الحسابي } \\
\hline & & & .65118 & 127 & البنين & \\
\hline \multirow[t]{2}{*}{.009} & \multirow[t]{2}{*}{2.637} & \multirow[t]{2}{*}{182} & .32576 & 57 & البنات & \multirow{2}{*}{ الاستعداد الرياضي } \\
\hline & & & .37731 & 127 & البنين & \\
\hline \multirow[t]{2}{*}{.000} & \multirow[t]{2}{*}{8.571} & \multirow[t]{2}{*}{182} & .37144 & 57 & البنات & \multirow{2}{*}{ العمليات الحسابية } \\
\hline & & & .45958 & 127 & البنين & \\
\hline \multirow[t]{2}{*}{.000} & \multirow[t]{2}{*}{9.755} & \multirow[t]{2}{*}{182} & .89224 & 57 & البنات & \multirow{2}{*}{ للاستدلال العام } \\
\hline & & & 1.20383 & 127 & البنين & \\
\hline
\end{tabular}




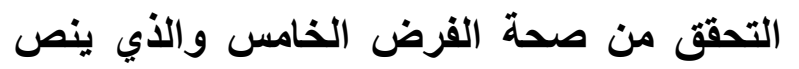

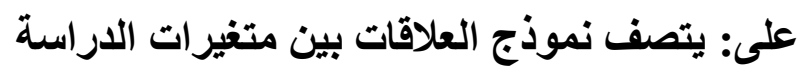

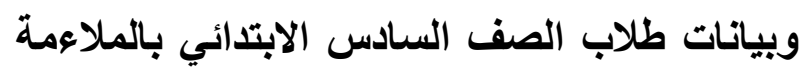
الإحصائية لبيانات الطلاب، كما تعكسها مؤشرات الملاءمة الإحصائية.

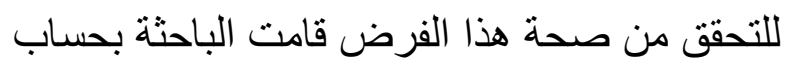

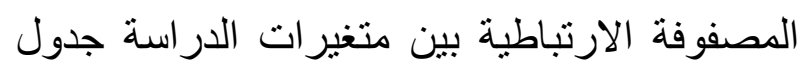

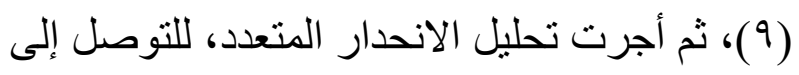

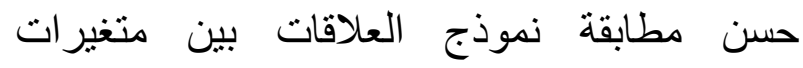
الدراسة، ووضع الدعادلة التنبؤية.
يتضح من جدول (^) وجود فروق في متوسط الدرجة الكلية للاستدلال العام، والاستعداد فروف في الحسابي

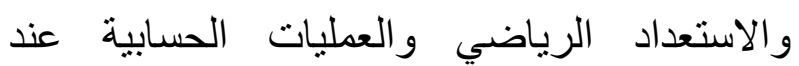
مسنوى دلالة 0.01 لصالح الإناث. ويفسر ذللك في ضوء تميز مدارس الإنة واهتمامهن بالتعليم بصورة اكبر من الذكور ـ كما فيا فئس

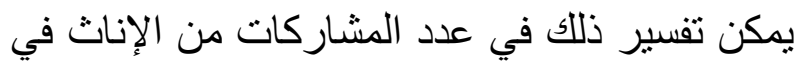

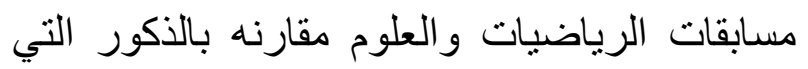

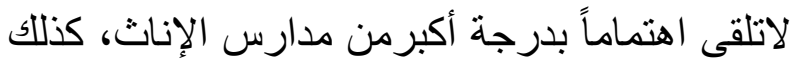

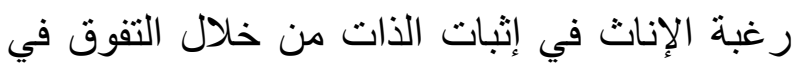
الرياضيات وبالتالي الاستدلال الرياضي.

جدول (9) يوضح المصفوفة الارتباطية بين متغيرات الاراسة لاى العينة الكلية

\begin{tabular}{|c|c|c|c|c|}
\hline للاستالال العام & العسابية & الاستعداد & الاستعداد & المتغيرات \\
\hline$\cdot .834$ & $\cdot .454$ & $\cdot .222$ & 1 & الاستعداد الحسابي \\
\hline$\cdot .579$ & $\cdot .276$ & 1 & $\cdot .222$ & الاستعاد الرياضي \\
\hline$\cdot .779$ & 1 & $\cdot .276$ & .454 & العمليات الحسابية \\
\hline 1 & $\cdot .779$ & $\cdot .579$ & $\cdot .834$ & الدرجة الكلية للاستدلال العام \\
\hline
\end{tabular}

المكونات المعرفية للاستدلال العام و الدرجة الكلية، ويوضح جدول (• () نتائج تحليل الانحدار المتعدد.
يتضح من جدول (9) دلالة جميع معاملات الارتباط بين متغير ات المصفوفة الارتباطية بين 
جدول (• 1 ) ملخص نموذج العلاقات بين المكونات المعرفية للاستدلال العام والدرجة الكلية

\begin{tabular}{|c|c|c|c|c|}
\hline الخطأ المعياري للتقدير & مربع R المعدل & R Rربع & $\mathbf{R}$ & النموذج \\
\hline$\cdots \cdots$ & $1, \ldots$ & $1, \ldots$ & $1.000 \mathrm{a}$ & 1 \\
\hline
\end{tabular}

المنبئات: (الثابت)، الاستعداد الحسابي، الاستعداد الرياضي، العمليات الحسابية

جدول (1 1) يوضح تحليل التباين الأحادي ANOVA

\begin{tabular}{|c|c|c|c|c|c|}
\hline الالالة & المربعات متوسط & درجات الحرية & المربعات & & النموذج \\
\hline \multirow[t]{3}{*}{.000} & rVYr, Ir & 3 & 8166.038 & الإتحدار & \multirow[t]{3}{*}{1} \\
\hline & .000 & 180 & .000 & البواقي & \\
\hline & & 183 & 8166.038 & الإجمالي & \\
\hline
\end{tabular}

جدول (r l ) يوضح معاملات الاتحدار للمكونات المعرفية للاستدلال العام والدرجة الكلية المتغير

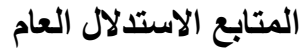

\begin{tabular}{|c|c|c|c|c|c|c|}
\hline \multirow[b]{2}{*}{ الدلالة } & \multirow[b]{2}{*}{ 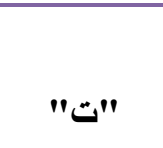 } & \multirow{2}{*}{$\begin{array}{c}\text { المعيارية المعاملات Beta } \\
\text { Beta }\end{array}$} & \multicolumn{2}{|c|}{ المعاملات غير المشبعة } & \multirow{2}{*}{\multicolumn{2}{|c|}{ النموذج }} \\
\hline & & & الخطأ المعياري & B & & \\
\hline .000 & $\cdots$ & & .000 & 0.000001 & (الثابت) & 1 \\
\hline .000 & 3.010E8 & 0.564 & .000 & 1.000 & الاستعداد الحسابي & \\
\hline .000 & $1.930 \mathrm{E} 8$ & 0.335 & .000 & 1.000 & الاستعداد الرياضي & \\
\hline .000 & $2.263 \mathrm{E} 8$ & 0.430 & .000 & 1.000 & العمليات الحسابية & \\
\hline
\end{tabular}

يتضح من نتائج الانحدار المتعدد مواءمة نموذج وبذللك يتحقق الفرض الخامس للار اسة ، ويوضح

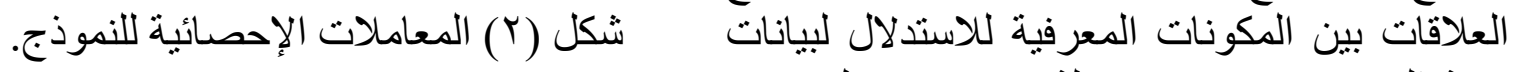

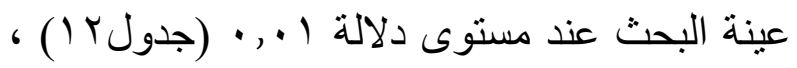




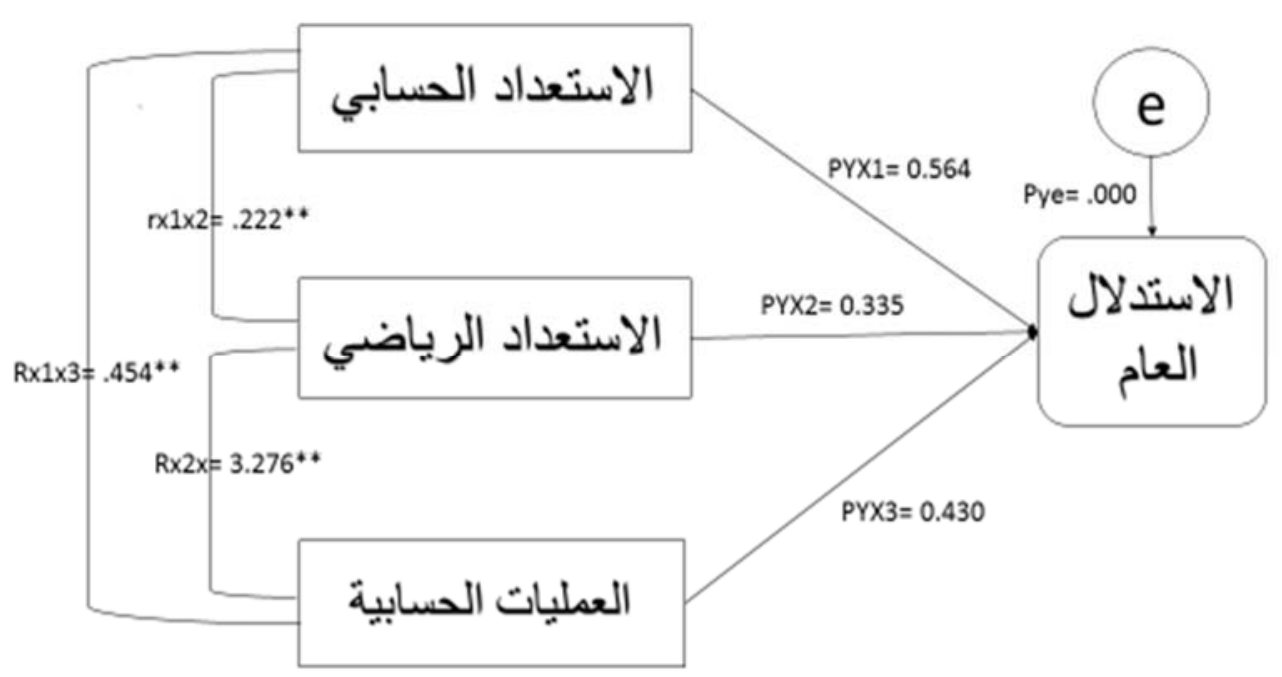

شكل (ץ) يمثل النموذج الإحصائي للعلاقات بين المكونات المعرفية للاستدلال في هذه الدراسة

بسومي (Y. . . . التي توصلت إلى أن أداء طلاب

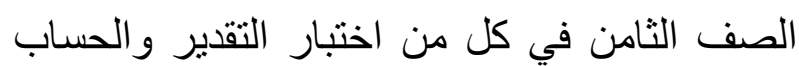
الذهني أفضل من أداء طلاب الصف السادس، وكان أداء طلبة الصف العاشر أفضل من أداء طلاب الصف السادس بينما لم تظهر فروق ذات دلالة إحصائية بين أداء طلاب الصفين. كما يُفسر في ضوء لين ارتباط الاستدلال العام بالتحصيل الدراسي في مادة الحساب و الرياضيات،

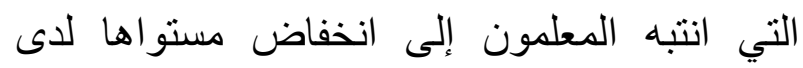
تلاميذ المرحلة الابتدائية من خلال ممارساتهم التعليمية ومن خلال نتائج البحوث و الدراسات،

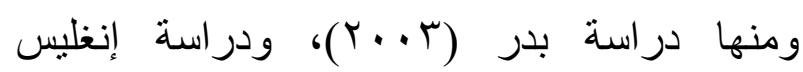

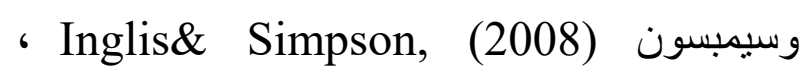

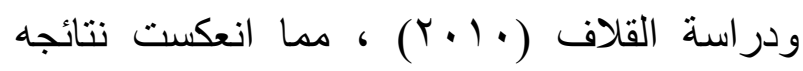
بمزيد من الجهد في هذه المقررات فأدى ذلك إلى
ويمكن تفسير الملاعمة الإحصائية لنموذج العلاقات

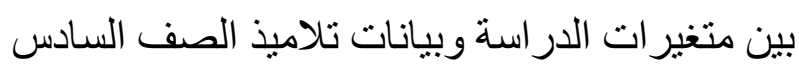
الابتدائي، في ضوء اختيرار المكونات المعرفية للاستدلال التي اقترحها أكستروم وزملاؤه، وبذللك تؤكد هذه النتائج الصدق البنائي للمقياس. تعليق عام على النتائج:

توصلت نتائج البحث إلى أن مستويات الاستدلال العام وجميع أبعاده الفرعية لدى العينة الكلية للبحث جميعها متوسطة ، وكذلك لدى عينة الذكور و وعينة الإناث، عدا بُعد الاستعداد الحسابي كانت درجته ورته كبيرة لدى عينة البحث من الإناث. وتبدو هذه النتائج متفقة مع العمر الزمني لعينة البحث وطبيعة الاستدلال لديها، هيث اثبت هذه الدراسات السابقة تحسن القدرة على الاستدلال بتقدم العمر في سني الطفولة والمراهقة ومنها دراسة 
Kalsoom, et al, دراسة كلسوم وآخرون

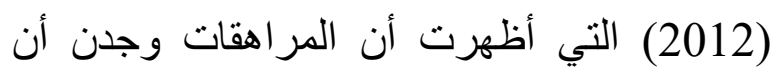

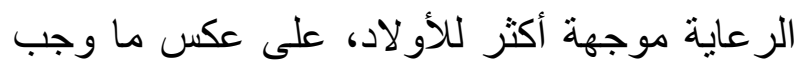

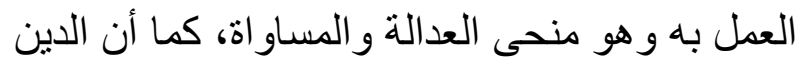

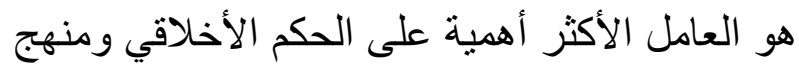
العدالة الموجهة لطلاب، وتدعم هذه النتائج جزئيا نظرية جيليجان, كون المعايير الثقافية لا تلعب دوراً

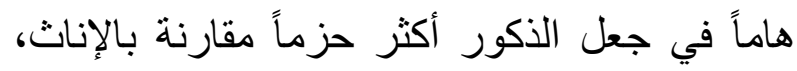
و أنه من المتوقع من الفتاة أن تكون منقادة، انطو ائية ومر اعية للأخلاق مقارنة بالذكور .

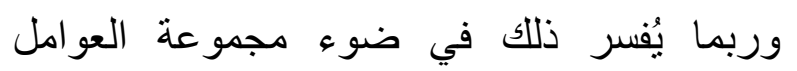

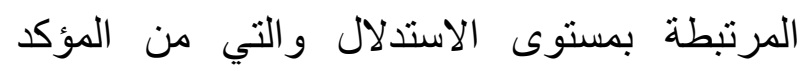

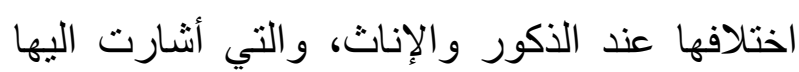

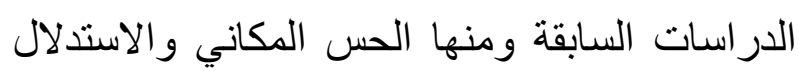

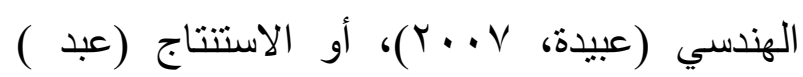

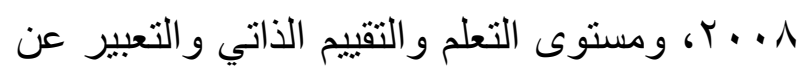

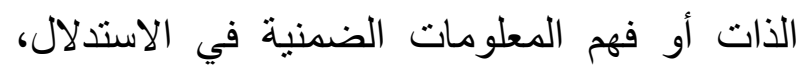

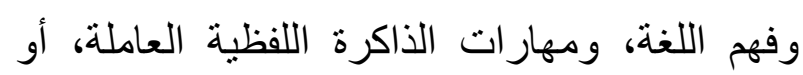

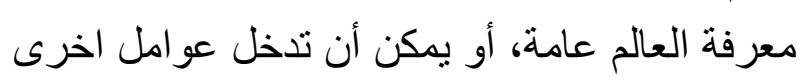

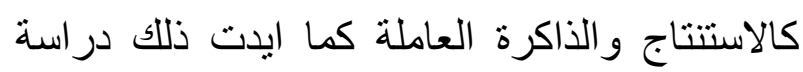
جروسنيكل وآخرين (2016) ورانة Markovits, ودراسة ماركوفايتس (2014) تطور الاستدلال الثرطي. ودراسة ديلازر وآخرين Delazer et al., (1999) بين الاستدلال الرياضي

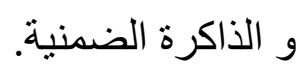
وربما يفسر ذللك أيضاً في ضوء الئه اختلاف

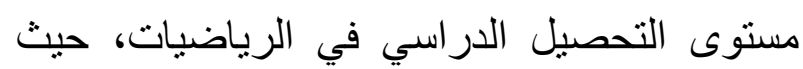

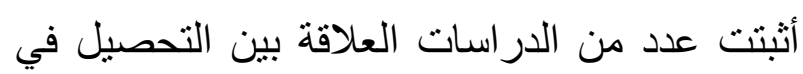

ارتفاع مستوى الاستدلال العام ليصبح منوسطاً بعد أن كان منخفضاّ.

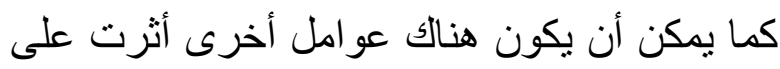
ارتفاع الاستدلال كما أظهرت دراس استة كاربلس

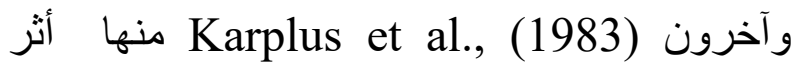
المهمة السابقة في توجيه الاستدلال الحالي التي أثبتت نأثر حل المشكلات الاستدلالية بالمهمة السابقة Delazer et مباثرة، ودراسة ديلازر وآخرون

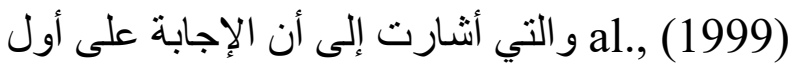

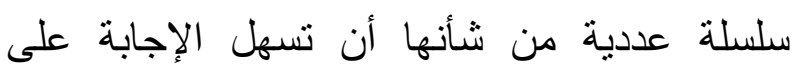
السلسلة العددية الثانية, و دراسة جروسنيكل وآخرين Grossnickle et al.( 2016) انخفاض استدلال الطلاب بسبب صعوبات الاستنتاج الناجمة عن العلاقة بين قدرة الذاكرة العاملة و عمليات الاستدلال ورسم الخر ائط.

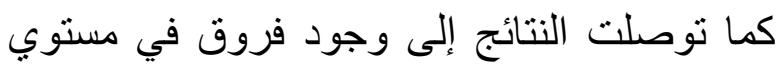
الدرجة الكلية للاستدلال العام، والاستعداد الحسابي في فئري

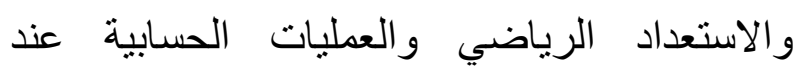

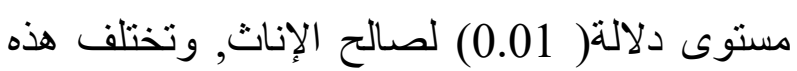
النتائج مع الدراسات السابقة التي تناولت التالت الفروق بين الجنسين في القدرة على الاستدلال ومنها دراسة

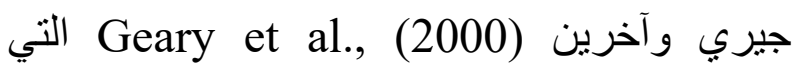
أظهرت تفوق الذكور على الإناث في القدرة

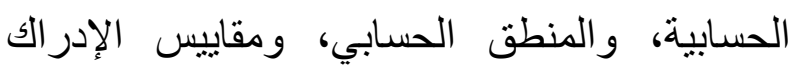

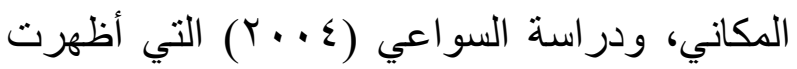
تفوق الذكور على الإناث في الاستدلال التناسبي،

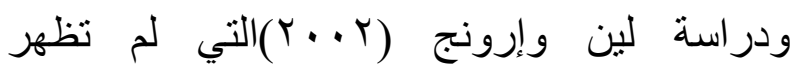
اختلافات في الاستدلال بين الذكور و الإناث وكذلك

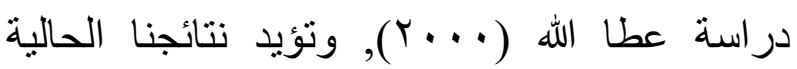


المعلومات، وممارسة عمليات الاستدلال القائم على معالجة المواد والأدوات بدوياً، وتمثيل الديله المفاهيم

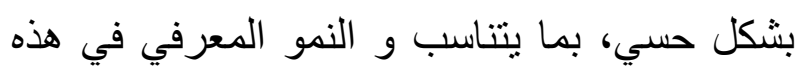
المرحلة النمائية.

- إجر اء در اسات للكثف عن الخصائص و الكفايات المهنية لمعلم الرياضيات الكفه ليتم في ضونئها اختيار المعلمين، ووضع البرامج التي تستهدف لئه اكساب المعلمين هذه المهار ات و الخصائص. ـ دراسة أسباب الفروق بين الذكور والإناث في هاب الذابن الاستدلال الرياضي وعلاقته ببعض العوامل الذاتية والسياقية، وبناء بر امج لتنمية الاستدلال لدى تناميذ الصف السادس الابتدائي تراعي النمو المعرفي وفقاً لنظريات مختلفة كنظرية بياجية في النمو المعرفي ليزي أو نظرية فيجوتسكي في النمو اللغوي، ودراسة فاعلية هذه البر امج من خلال الدر اسات التجريبية.

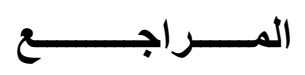

أبو حطب، فؤاد؛ صادق، آمال ( 99 (1). علم النفس التربوي. القاهرة: مكتبة الانجلو المصرية.

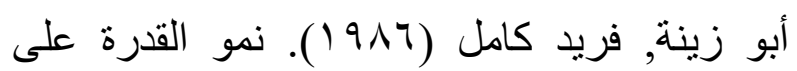
التفكير الرياضي عند الطلبة في مرحلة الدراسة الثانوية وما بعدها. المجلة العربية للعلوم الإنسانية

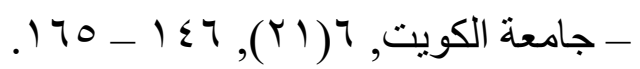
أكستروم، فرنش، وهارمان، وديرمين (1997 (19).

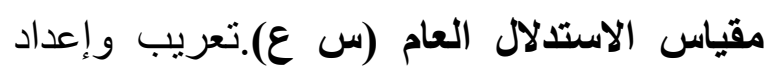
أنور محمد الثرقاوي، سليمان الخضري الثيخ،

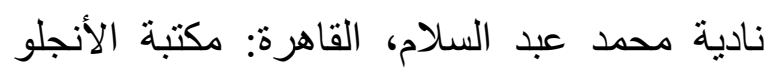
المصرية.

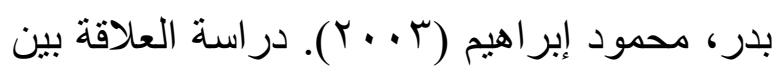
الاستدلال المنطقي و التحصيل في الرياضيات
الرياضيات والاستدلال ، فربما يرجع تفوق الإناث

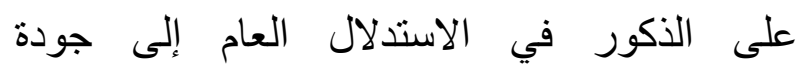
الممارسات التعليمية في المقررات الدراسة عامة وفي مقررات الرياضات بصفة خاصة في مدارس الإناث عن مدارس الذكور , مما بدعم دراسة أثر

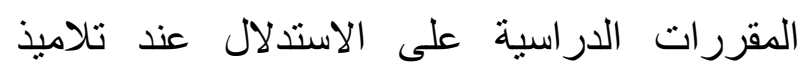
المدارس. - ارس كذلك كيفية قياس المعلم لأدائه لدى التلاميذ يمكن

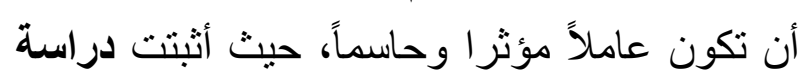
كوليتا وآخرين (2007 ),. Coletta et al , أن العديد Force Concept من المعلمين يطبقون اختبار Iلى الابهم في محاولة Invento 1,2 (FCI) لتقييم وتحسين ممارساتهم التعليمية على حين أن هذا وحده لايكفي وإنما يجب قياس مدى مستوى الاستدلال لتحديد الطلاب منخفضي المستوى الذين ولانيا هم في خطر اكاديمي. يؤيد ذلك أيضا دراسة زاهو وآخرين Zhao

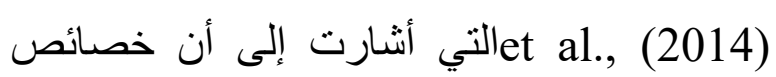
الطلاب (الجنس، العمر، ما وراء المعرفة، وفعالية الذات في الرياضيات)، و العوامل السياقية الخارجية (المعدل الأكاديمي، المستوى التعليمي للمعلمين ولئي

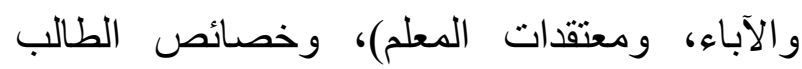
الأخرى والسياقية تؤثر بطرق مباثرة أو غير ولير

$$
\text { مباشرة على الاستدلال. }
$$

ـ الاهتمام بتضمين مهار ات الاستدلال فى مناهج المرحلة الابتدائية في: مواقف التعليم , التعلم وتنمية

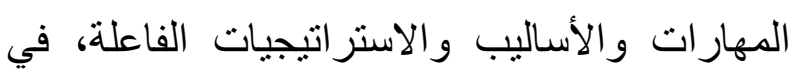
تتشيط الطلاب عموماً وعدم الاقتصار على تلقين 
طالبات المرحلة المتوسطة. رسالة ماجستير ، كلية التربية، الجامعة: جامعة الطائف.

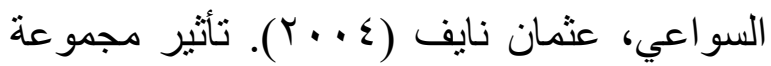

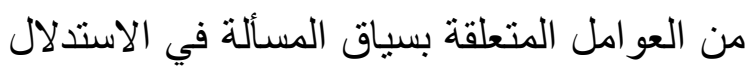

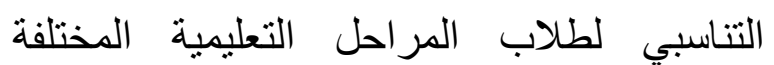
وإمكانية إنتقال أثر التعلم من خبرة إلى أخرى.

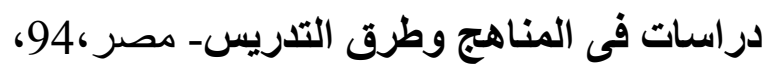
$225-202$

الثيخ، سليمان الخضري(19192). الفروق الفردية في الذكاء. القاهرة: دار الثقافة للطباعة و النشر.

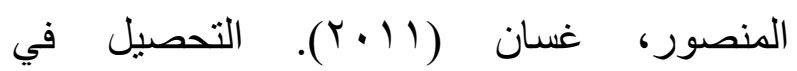
الرياضيات وعلاقته بمهارات التفكير دراسة التهان ميدانية على عينة من تلامذة الصف السادس الأساسي في مدارس مدينة دمشق الرسمية. مجلة منية

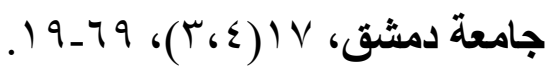

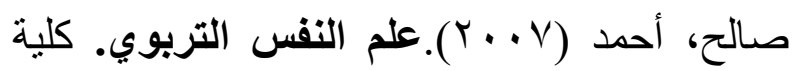
التربية- جامعة الاسكندرية.

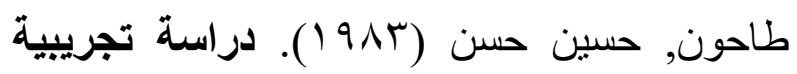
لأثر الإستعدادات المعالجات عند تلاميذ المرحلة الثانوية في تحصيلهم مادة الرياضيات .رسالة

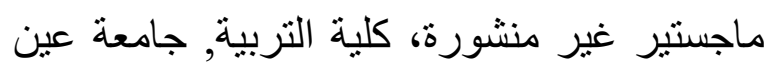
شمس, القاهرة, مصر.

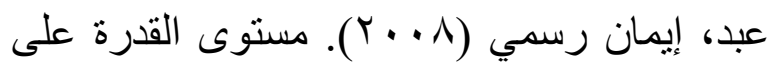
الاستدلال التناسبي لاى طلبة المرحلة الأساسية

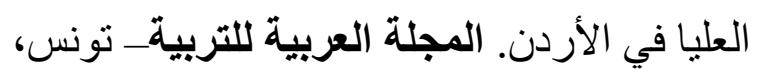

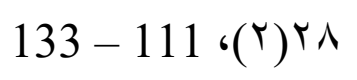

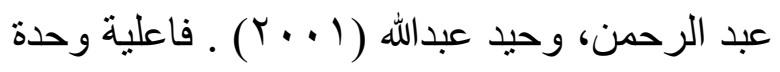
مقترحة في المنطق الرياضي علي أداء طلاب

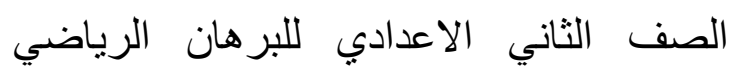

لاى طلاب المرحلة المنوسطة و الثانوية بالرياض.

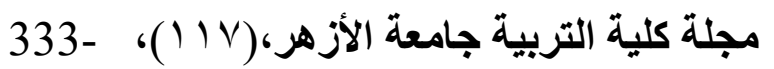
295

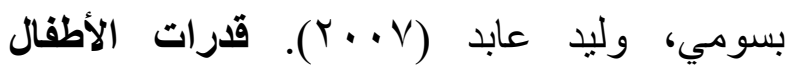
الفلسطينيين للصفوف السادس والثامن والعاثر في تقدير نواتج العمليات الحسابية وإجراء الحساب الذهني. ماجستير. التربية. جامعة بيرزيت. كلية الدر اسات العليا، رام الله، فلسطين.

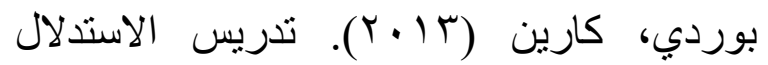

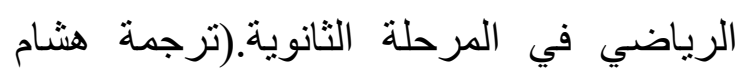
بركات مصطفى عبدالسميع). مجلة تربويات

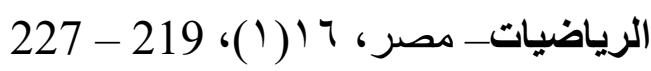

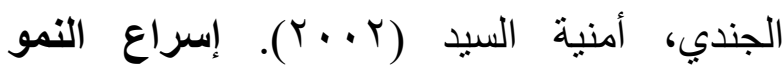

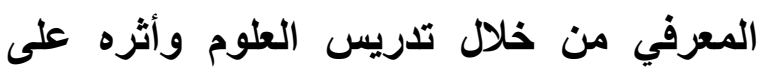

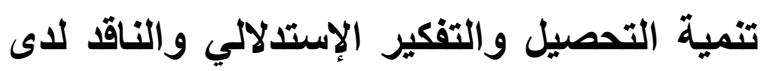
تلاميذ الصف الثالث الإعدادي. الجمعية المصرية

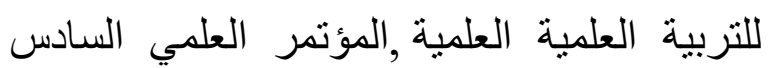
للتربية العلمية وثقافة المجتمع رالمجلد الثاني.

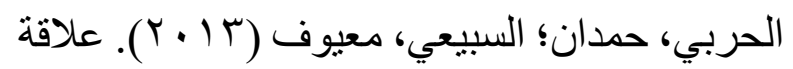

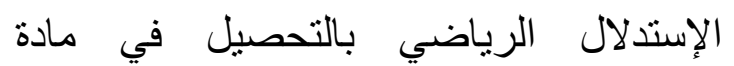

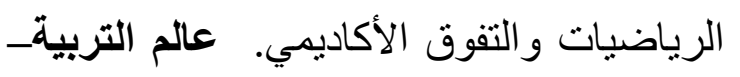

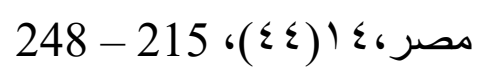

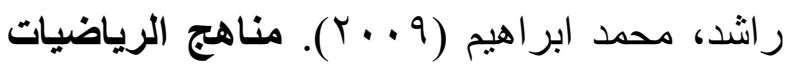

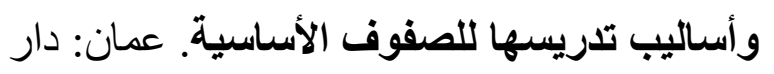
الجنادرية للنشر و التوزيع.

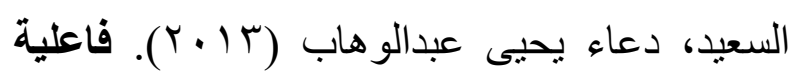
استخدام استراتيجية حل المشكلات مفتوحة النهاية في تنمية مهارات الاستدلال الرياضي لدى الدئي 
نجم، خميس موسى (Y (Y (Y). أثز برنامج تدريبي لتنمية التفكير الرياضي في تحصيل طلبة الصف موني السابع الأساسي في الرياضيات. مجلة جامعة

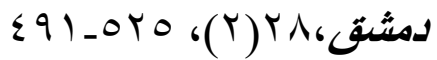

$$
\begin{aligned}
& \text { ثناتيا: المراجع الاجنبية }
\end{aligned}
$$

Beyer, B. K. (1987). Practical strategies for the teaching of thinking. Boston: Allyn and Bacon.

Barbey, A., \& Barsalou, W., (2009). Reasoning and Problem Solving: Models. Encyclopedia of Neuroscience, 8, 35-43.

Carson S., (1984). Reasoning Michael Scriven. Informal Logic , 2(2), 17-18

Delazer, M., Girelli, L. \& Benke, T. (1999). Arithmetic Reasoning and Implicit Memory: A Neuropsychological Study on Amnesia. Cortex. 35 (5), 615-627

Drager, K., (2014). The Relationship between Abstract Reasoning and Performance in High School Algebra. Submitted to the graduate degree program in Psychology and Research in Education and the graduate faculty of the University of Kansas in partial fulfillment of the degree of Master of Science.

Hunter J., (2010). Developing early algebraic reasoning through exploration of the commutative principle. Joubert, $M$. and Andrews, P. (Eds.) Proceedings of the British Congress for Mathematics Education April 2-34

https://www.ets.org/Media/Research/pdf/Manu al_for_Kit_of_Factor-

Referenced Cognitive Tests.pdf

Geary D, Saults S, Liu F, Hoard M. (2000). Sex differences in spatial cognition, computational fluency, and arithmetical reasoning. J Exp Child Psychol. 77(4), 337-353.

Grossnickle, E. M., Dumas, D., Alexander, P. A., \& Baggetta, P. (2016). Individual differences in the process of relational

$$
\begin{aligned}
& \text { والاستدلال المنطقي. مجلة العلوم التربوية } \\
& \text { والنفسية_ البحرين، ؟(ץ)، } 166 \text { - } 167
\end{aligned}
$$

. kenanaonline.com/files/0020/20135/

عطا الله، ميشيل كامل (ع ... (Y). تطور مستوى فهم عمليتي الملاحظة والاستدلال لاى طلبة الصفين الثالث و السادس الأساسيين في مادة العلوم في مدارس محافظة الزرقاء التابعة لوكالة الغوث

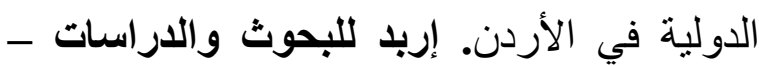

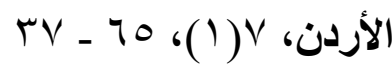

قاموس المعاني الجامعه، مادة استدل، تم استرجاعه

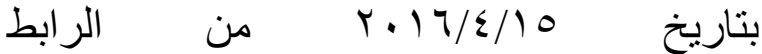

www.almaany.com/ar/dict/ar-ar/

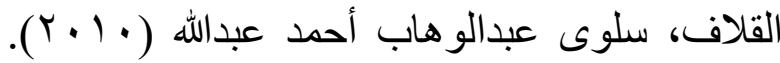
أثر وحدة إثرائية في مادة الرياضيات على تنمية الاستدلال المكاني و تحسين التحصيل في الهندسة لاى تلميذات الصف الخامس الابتدائي في دولة الكويث. رسالة ماجستير غير منشورة ، كلية الدر اسات العليا، جامعة الخليج العربي.

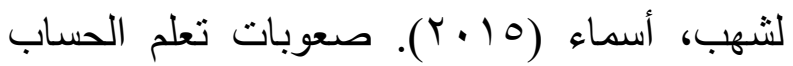
لاى تلاميذ المدرسة الابتدائية و أساليب علاجه. مجلة دراسات نفسية وتريوية ـ جامعة قاصدي

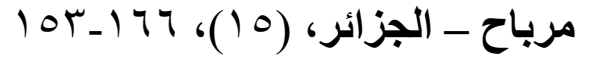

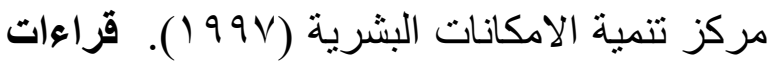
فى مهارات التفكير وتعليم التفكير الناقد، والتفكير الابداعي. تعريب : فيصل يونس، القاهر: دار

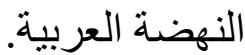


Literacy. Annual Meeting, Amherst College, April 29.

Markovits, H. (2014). On the road toward formal reasoning: Reasoning with factual causal and contrary-to-fact causal premises during early adolescence. Journal of Experimental Child Psychology, 128, 3751 .

Naik, S., Banerjee, R., \& Subramaniam, K. (2005). Understanding student's reasoning while comparing expressions. In $P$. Clarkson, et. al. (Ed.), Proceedings of the Annual Conference of the Mathematics Education Research Group of Australasia. Melbourne, Australia: MERGA.

Schoenfeld, A. H. (1992). Learning to think mathematically: Problem solving, metacognition, and sense-making in mathematics. In D. Grouws (Ed.), Handbook for Research on Mathematics Teaching and Learning (pp. 334-370). New York: MacMillan.

Singley, A., \& Bunge, S., (2014). Neurodevelopment of relational reasoning: Implications for mathematical pedagogy. Trends in Neuroscience and Education, 3, 33-37

Smith, J., \& Thompson, P. W. (2007). Quantitative reasoning and the development of algebraic reasoning. In J. J. Kaput, D. W. Carraher \& M. L. Blanton (Eds.), Algebra in the early grades (pp. 95-132). New York: Erlbaum.

Zhao, N., Valcke, M., Desoete, A. Zhu, C. \& Sang, G. Y. (2014). A holistic model to infer mathematics performance: the interrelated impact of student, family and school context variables. The Scandinavian Journal of Educational Research. 58(1), 1-20. reasoning. Learning and Instruction, 42, 141-159.

Inglis, M. \& Simpson, A. (2008). Conditional inference and advanced mathematical study. Educational Studies in Mathematics 67(3), 187-204.

Karplus, R., Pulos, S., \& Stage, E., (1983). Early Adolescents' Proportional Reasoning on 'Rate' Problems. Educational Studies in Mathematics. 14(43), 219-233.

Kalsoom, F., Behlol, M.G., Kayani, M.M., \& Kaini, A. (2012) the moral reasoning of adolescent boys and girls in the light of Gilligan's theory, International Education Studies. 5(3).

Knuth, E., Kalish, C., Ellis, A., Williams, C., \& Felton, M. (2011). Adolescent reasoning in mathematical and nonmathematical domains: Exploring the paradox. To appear in V. Reyna, S. Chapman, M. Dougherty, \& J. Confrey (Eds.), the adolescent brain: Learning, reasoning, and decision making. Washington, DC: American Psychological Association.

Kosyvas, G., (2016). Levels of arithmetic reasoning in solving an open-ended problem. International Journal of Mathematical Education in Science and Technology. 47 (43), 356-372.

Linn M., \& Levine D., (1977). Scientific resoning ability in adolescence: theoretical viewpoints and educational implications. Journal of research in science teaching, 14(4), 371-384

Lynn R., Irwing P. (2002). Sex differences in general knowledge, semantic memory and reasoning ability. Br J Psychol. 93(4), 54556.

Madison, Bernard. (2006). Presentation to the Northeast Consortium on Quantitative 


\title{
Model of the Relations Between the Cognitive Components of the Reasoning and Its Level Among the Sixth-Grade Pupils in Shaqra Governorate (A Comparative Study Between the Sexes)
}

\author{
Asma Farraj bin Khalawi \\ Assistant Professor of Psychology - University of Shaqra, Saudi Arabia
}

\begin{abstract}
The study aimed to study the level of general reasoning among sixth graders-a comparative study,between males and females, and verify the good match model relationships between the cognitive components of the inferred search data.The study sample that is consisted of (184) students in sixth grade (127) males, and (57) females whom were sat to the general reasoning test, prepared by (French et al.) translated by (Sheikh et al. ,1996), after verifying its validity and stability using "T" test, then regression analysis.The results of the study showed that the general reasoning and total sub-dimensions (mathematical readiness, arithmetic readiness, and mathematical calculations) were all of the average in the male sample, and the female sample and the total sample, except that the - arithmetic readiness was high in the female sample. There were also differences in both general reasoning, arithmetic readiness and mathematical readiness, and mathematical calculations between males and females at the level of $\alpha=(0.01)$ for females. The results also indicated the quality of corresponding the model of relations between the cognitive components of the analysis of the study data, the results were then discussed and recommendations and proposals presented.

Key Words: General Inference, Arithmetic Readiness, Mathematical Readinessm Mathematical Calculations Sixth Grade Pupils
\end{abstract}

